University of South Florida

DIGITAL COMMONS

@ UNIVERSITY OF SOUTH FLORIDA
Digital Commons @ University of

South Florida

$5-1-2017$

\title{
Public Transit to Public Lands: The Nature Express
}

CUTR

Follow this and additional works at: https://digitalcommons.usf.edu/cutr_nctr

\section{Recommended Citation}

"Public Transit to Public Lands: The Nature Express," National Center for Transit Research (NCTR) Report No. CUTR-NCTR-RR-2017-04, Center for Urban Transportation Research, University of South Florida, 2017. DOI: https://doi.org/10.5038/CUTR-NCTR-RR-2017-04

Available at: https://scholarcommons.usf.edu/cutr_nctr/49

This Technical Report is brought to you for free and open access by the National Center for Transit Research (NCTR) Archive (2000-2020) at Digital Commons @ University of South Florida. It has been accepted for inclusion in Research Reports by an authorized administrator of Digital Commons @ University of South Florida. For more information, please contact digitalcommons@usf.edu. 


\title{
Public Transit to Public Lands: The Nature Express
}

\author{
Final Report
}

Prepared for:

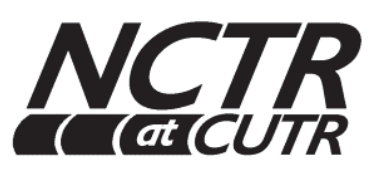

National Center for Transit Research

University of South Florida

Prepared by:

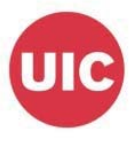

Urban

Transportation

Center

The Urban Transportation Center

at the University of Illinois at Chicago

412 South Peoria Street, 340 CUPPAH

Chicago, IL 60607-7036

P.S. Sriraj, PhD

David Fullarton, MUPP

May 2017 


\section{Disclaimer}

The contents of this report reflect the views of the authors, who are responsible for the facts and the accuracy of the information presented herein. This document is disseminated under the sponsorship of the U.S. Department of Transportation's University Transportation Centers Program, in the interest of information exchange. The U.S. Government assumes no liability for the contents or use thereof. 
TECHNICAL REPORT STANDARD TITLE PAGE

\begin{tabular}{|c|c|c|}
\hline 1. Report No. & 2. Government Accession No. & 3. Recipient's Catalog No. \\
\hline \multirow{2}{*}{\multicolumn{2}{|c|}{$\begin{array}{l}\text { 4. Title and Subtitle } \\
\text { Public Transit to Public Lands: The Nature Express }\end{array}$}} & $\begin{array}{l}\text { 5. Report Date } \\
\text { May } 2017\end{array}$ \\
\hline & & 6. Performing Organization Code \\
\hline \multicolumn{2}{|c|}{$\begin{array}{l}\text { 7. Author(s) } \\
\text { P.S. Sriraj, PhD; David Fullarton, MUPP }\end{array}$} & 8. Performing Organization Report No. \\
\hline \multirow{2}{*}{\multicolumn{2}{|c|}{$\begin{array}{l}\text { 9. Performing Organization Name and Address } \\
\text { The Urban Transportation Center at the University of Illinois Chicago } \\
412 \text { South Peoria Street, } 340 \text { CUPPAH } \\
\text { Chicago, IL 60607-7036 }\end{array}$}} & 10. Work Unit No. (TRAIS) \\
\hline & & 11. Contract or Grant No. \\
\hline \multirow{3}{*}{\multicolumn{2}{|c|}{$\begin{array}{l}\text { 12. Sponsoring Agency Name and Address } \\
\text { National Center for Transit Research } \\
\text { Center for Urban Transportation Research } \\
\text { University of South Florida } \\
4202 \text { East Fowler Avenue, CUT100, Tampa, FL 33620-5375 }\end{array}$}} & 13. Type of Report and Period Covered \\
\hline & & \\
\hline & & 14. Sponsoring Agency Code \\
\hline
\end{tabular}

15. Supplementary Notes

16. Abstract

Access to leisure by public transportation has not been studied in great detail, at least in the United States. The Northeastern Illinois region with the City of Chicago (in Cook County) as the focal point is home to the third largest public transportation system in the country. The transit network is well connected and serves the traditional commute and other associated trips in an adequate manner. However, the access by public transportation to leisure activities and destinations has not been studied extensively. This study focuses on that aspect of travel in a large metro area in order to highlight the adequacy of the existing transit network in catering to the needs of the transportation disadvantaged population groups.

\begin{tabular}{|l|l|l|l|}
\hline \multicolumn{2}{|l|}{ 17. Key Words } & \multicolumn{2}{|l|}{ 18. Distribution Statement } \\
\hline $\begin{array}{l}\text { 19. Security Classif. (of this report) } \\
\text { Unclassified }\end{array}$ & $\begin{array}{l}\text { 20. Security Classif. (of this page) } \\
\text { Unclassified }\end{array}$ & 21. No. of Pages & 22. Price \\
\hline
\end{tabular}

Form DOT F 1700.7 


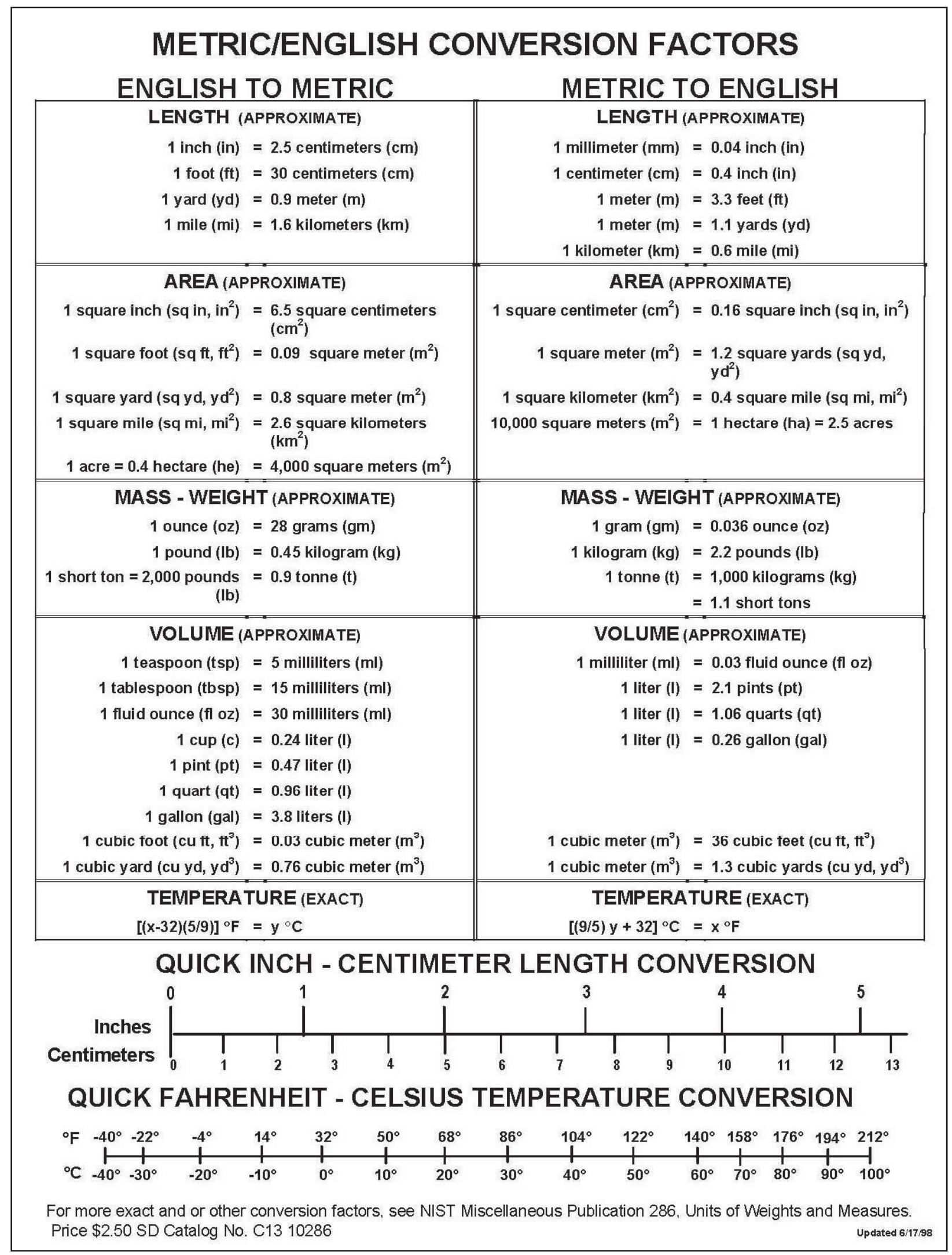




\section{Table of Contents}

$\begin{array}{ll}1.0 \text { Acknowledgement } & 4\end{array}$

$\begin{array}{ll}2.0 \text { Introduction } & 4\end{array}$

3.0 Identification of Target Population 4

$\begin{array}{ll}\text { 3.1 Environmental Justice Areas } & 4\end{array}$

$\begin{array}{ll}\text { 3.2 Transit Dependent (TD) Areas } & 7\end{array}$

3.3 Cook County Forest Preserve District Nature Centers 11

$\begin{array}{ll}\text { 4.0 Preliminary Cook County Data } & 17\end{array}$

5.0 Transit Availability and Accessibility to Nature Centers Using GTFS Data 18

6.0 Location Summaries for FPDCC Nature Centers 20

$\begin{array}{ll}\text { 6.1 Crabtree Nature Center } & 20\end{array}$

6.2 River Trail Nature Center 21

$\begin{array}{ll}6.3 \mathrm{Hal} \text { Tyrrell Trailside Museum } & 24\end{array}$

6.4 Little Red Schoolhouse Nature Center $\quad 27$

6.5 Sand Ridge Nature Center 30

6.6 Sagawau Environmental Learning Center 33

$\begin{array}{ll}7.0 \text { Express Routings } & 35\end{array}$

$\begin{array}{ll}8.0 \text { Conclusions } & 40\end{array}$

$\begin{array}{ll}9.0 \text { References } & 40\end{array}$

\section{List of Figures}

$\begin{array}{ll}\text { Figure 1: Cook County Environmental Justice (EJ) Tract Map } & 6\end{array}$

$\begin{array}{ll}\text { Figure 2: Zones of Maximum EJ Criteria Met } & 7\end{array}$

Figure 3: Cook County Transit Dependency 99

Figure 4: Zones of Maximum TD Criteria Met 10

Figure 5: FPDCC Nature Center Locations 12 
Figure 6: Transit \& Roadways in Cook County

Figure 7: Bus Transit - FPDCC land within $1 / 4$ mile of CTA Bus \& Pace Stops

Figure 8: Rail Transit - FPDCC land within $1 / 2$ mile of CTA Rail \& Metra Stops

Figure 9: Crabtree 15, 30, 45, 60 \& 90-minute Transit Radius (Saturday \& Wednesday, 10:00a)

Figure 10: River Trail 15, 30, 45, 60 \& 90-minute Transit Radius (Saturday, 10:00a)

Figure 11: River Trail 15, 30, 45, 60 \& 90-minute Transit Radius (Wednesday, 10:00a)

Figure 12: Trailside Museum 15, 30, 45, 60 \& 90-minute Transit Radius (Saturday, 10:00a)

Figure 13: Trailside Museum 15, 30, 45, 60 \& 90-minute Transit Radius (Wednesday, 10:00a) 26

Figure 14: Little Red Schoolhouse 15, 30, 45, 60 \& 90-minute Transit Radius (Saturday, 10:00a) 28

Figure 15: Little Red Schoolhouse 15, 30, 45, 60 \& 90-minute Transit Radius (Wednesday, 10:00a) 29

Figure 16: Sand Ridge 15, 30, 45, 60 \& 90-minute Transit Radius (Saturday, 10:00a) 31

Figure 17: Sand Ridge 15, 30, 45, 60 \& 90-minute Transit Radius (Wednesday, 10:00a) 32

Figure 18: Sagawau 15, 30, 45, 60 \& 90-minute Transit Radius (Saturday \& Wednesday, 10:00a) 34

Figure 19: EJ Zone 1 Nature Express Routing 36

Figure 20: EJ Zone 2 Nature Express Routing 37

Figure 21: EJ Zone 3 Nature Express Routing $\quad 38$

Figure 22: EJ Zone 4 Nature Express Routing $\quad 39$ 


\subsection{Acknowledgement}

This work was sponsored by the Illinois Department of Transportation and through the Metropolitan Transportation Support Initiative (METSI), a program managed by the Urban Transportation Center at the University of Illinois at Chicago. This research is funded by the United States Department of Transportation through the National Center for Transit Research within the Center for Urban Transportation Research at the University of South Florida.

\subsection{Introduction}

Access to leisure by public transportation has not been studied in great detail, at least in the United States. The Northeastern Illinois region with the City of Chicago (in Cook County) as the focal point is home to the third largest public transportation system in the country. The transit network is well connected and serves the traditional commute and other associated trips in an adequate manner. However, the access by public transportation to leisure activities and destinations has not been studied extensively. This study focuses on that aspect of travel in a large metro area in order to highlight the adequacy of the existing transit network in catering to the needs of the transportation disadvantaged population groups.

UIC-UTC worked with the Forest Preserve District of Cook County to identify a hypothetical public transportation option which would allow Environmental Justice and Transit Dependent residents of Cook County to visit one of FPDCC's six nature centers. These two population groups, public transportation, and the six nature centers are spread throughout the County, which makes this research task both a challenge and an opportunity.

The approach for the study was divided into three parts. (1) Identification of the target population in Cook County, (2) Identification of the proximate bus stops and train stations to the Nature Centers, (3) Evaluation of the transit availability and accessibility from the origins (target population) to the destination (nature centers) using GTFS data and other spatial analysis tools. The results are discussed followed by policy recommendations and future work. The demographic analysis is discussed next.

\subsection{Identification of Target Population}

\subsection{Environmental Justice (EJ) Areas}

The UTC team developed an index to identify the target population that is likely to be disadvantaged due to the lack of access to forest preserves. The target population identification is done in different ways. The first approach is based on the principles of Environmental Justice (EJ). EJ stems from an 
Executive Order 1294, signed in 1994 and states that any action in the transportation domain should not disadvantage (1) racial minorities or blacks, (2) ethnic minorities, (3) low-income or economic minorities. Accordingly, Cook County is analyzed at the census tract level wherein, tracts are labeled as either EJ tracts or non-EJ tracts based upon the percent of population from each category described above and benchmarked against the regional population percent for each of those categories. Tracts are labeled as EJ tracts in 1, 2, 3 or all based upon the mix of population by category within each tract. For example, a tract can be labeled 1, if the percent of black population in the tract exceeds the regional black population percentage and so on. In this report, we consider any tract meeting $3 / 3 \mathrm{EJ}$ criteria as being "highly" EJ.

The following map depicts the Environmental Justice census tracts that have a value of 1, 2, or 3 based on three factors: $>50 \%$ Minority Population, $>50 \%$ African-American population, and $>50 \%$ of population under the poverty line. Tracts that have met any EJ criteria are displayed in blue; a lighter shade indicates that only one of these criteria has been met, with other tracts which meet two and three of the three possible measures of EJ displayed in correlating darker shades of blue. Those tracts which have not met any EJ criteria are displayed in a soft pink color. 
Figure 1: Cook County Environmental Justice (EJ) Tract Map

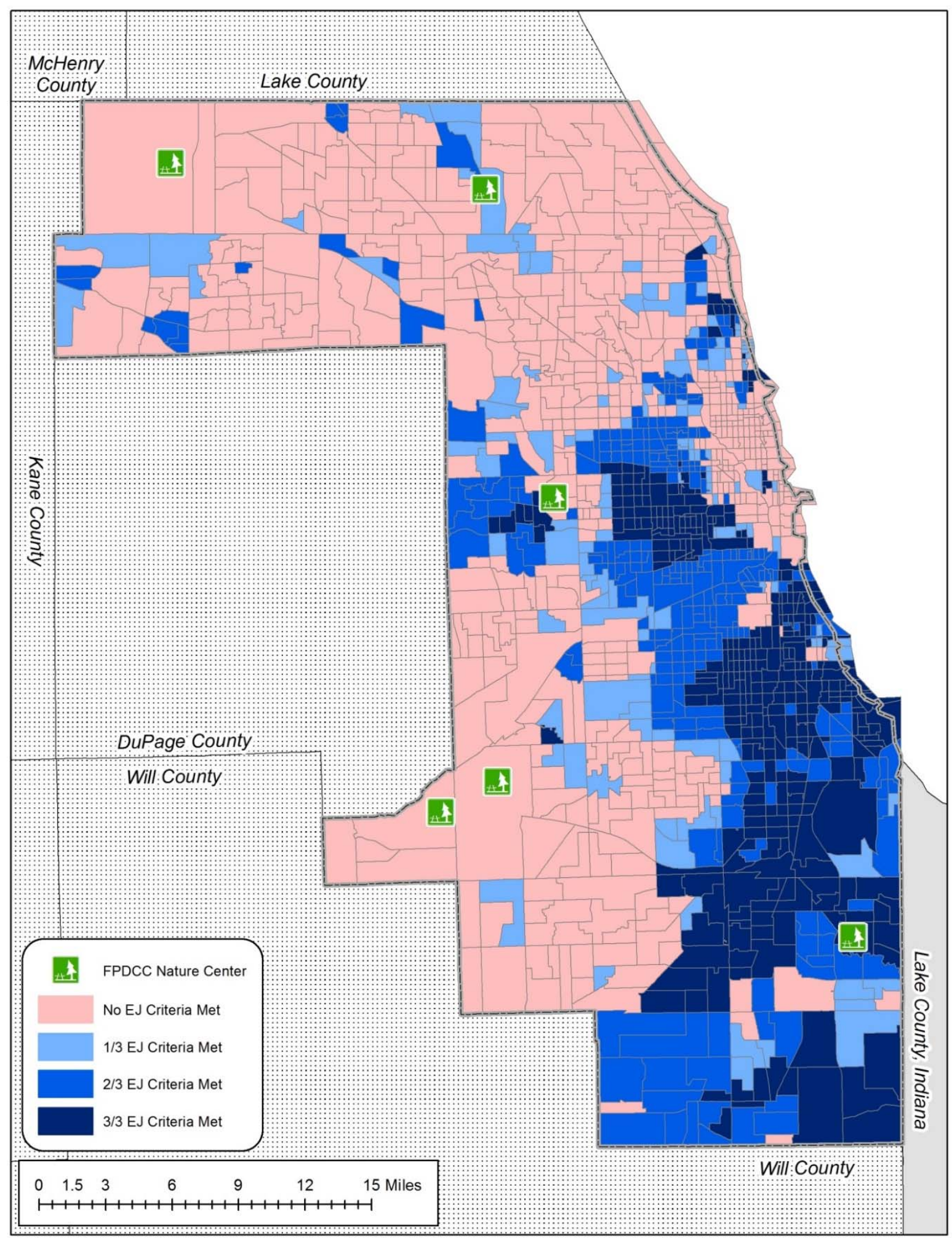


In order to better manage the geographical spread of Max EJ tracts throughout Cook County, the total grouping of all Max EJ tracts was divided into four zones. Additionally, each zone's centroid was generated using GIS software. We feel that generating these four zones is beneficial for this study as it will potentially lay the groundwork for multiple Nature Express services which can serve several different EJ areas of Cook County.

Figure 2: Zones of Maximum EJ Criteria Met

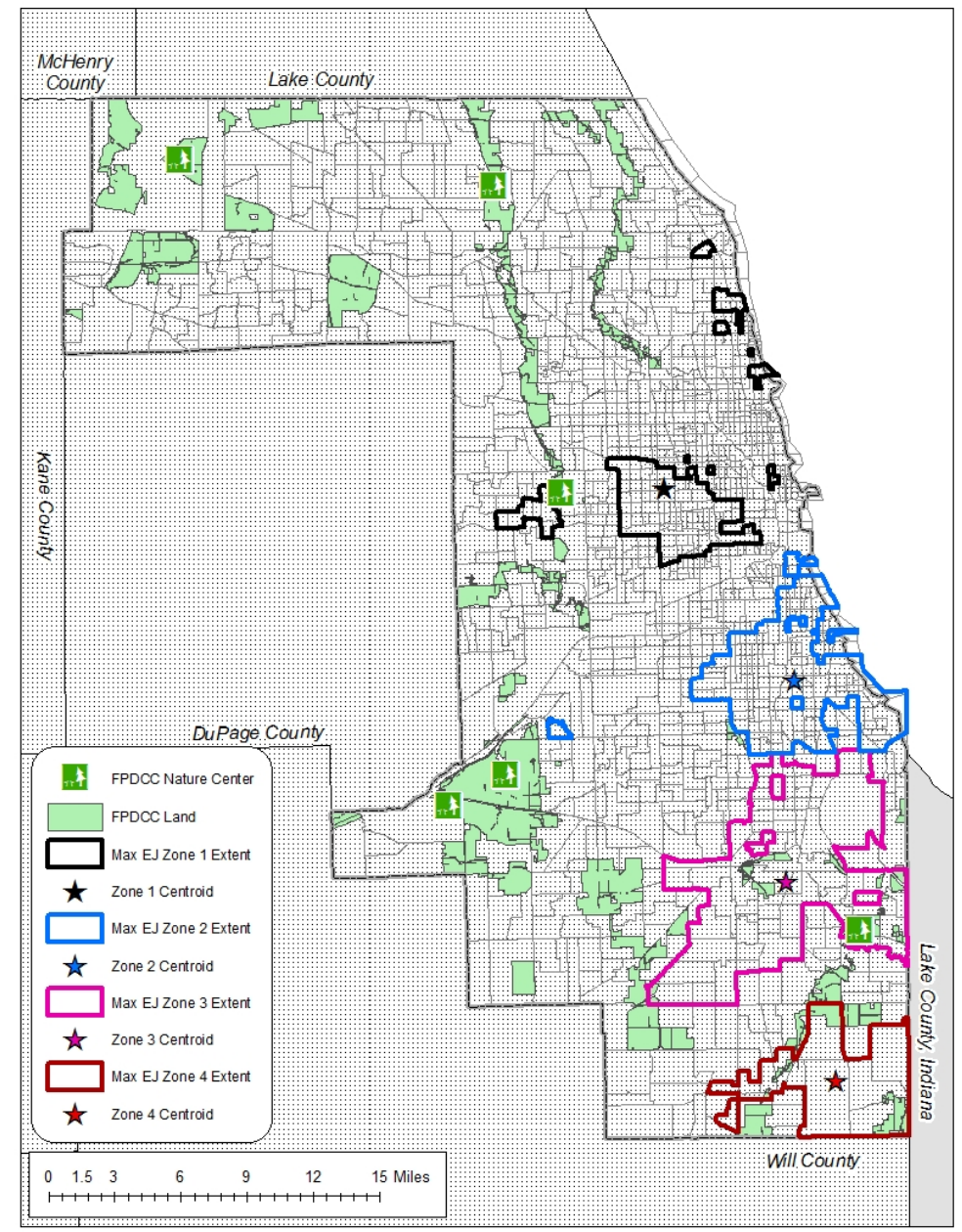

Max EJ Zone 1 (Black)

Area: 24.72 sq miles

Approximate Centroid: 852 N Kolin Ave, Chicago

Max EJ Zone 2 (Blue)

Area: 41.18 sq miles

Approximate Centroid: 6920 S Michigan Ave, Chicago

Max EJ Zone 3 (Pink)

Area: 71.5 sq miles

Appoximate Centroid: 14150 S Stewart Ave, Riverdale

Max EJ Zone 4 (Maroon)

Area: 29.43 sq miles

Approximate Centroid: 1205 E Lincoln Highway, Ford Heights 


\subsection{Transit Dependent (TD) Areas}

The other method of identifying the target population is by using an index developed by the PI, Dr. Sriraj. The index is labeled as a transit dependency index and is on a scale of low to high. The demographic factors included for consideration in this analysis are age (less than 18 , and greater than 65), poverty level, auto ownership (zero car households), and mode to work (public transit). This group, identified as transit dependent populations is a representation of census tracts that have a greater percent of any or all of these groups when compared to the regional (six-county) average for that category. Tracts that are tabbed as transit dependent are displayed in the map. The scaling of this index includes low, medium-low, medium-high, and high. Tracts considered highly Transit Dependent are those which meet $4 / 5$ or $5 / 5$ of the applicable criteria (noted above).

The following map depicts tract Transit Dependency (TD) measures from None to High. TD is measured in terms of: Significant population under 18 years old, significant population over 65 years old, significant population below the poverty level, significant population relying on transit to travel to/from work, and significant population with no vehicles in the household. Each criteria met/unmet is weighted equally among all others. If met, it contributes one of a possible five points in the measure of TD. For example, a census tract with one criteria met would be considered to have low transit dependency, but a tract with four out of five criteria met would be considered highly transit dependent. 
Figure 3: Cook County Transit Dependency

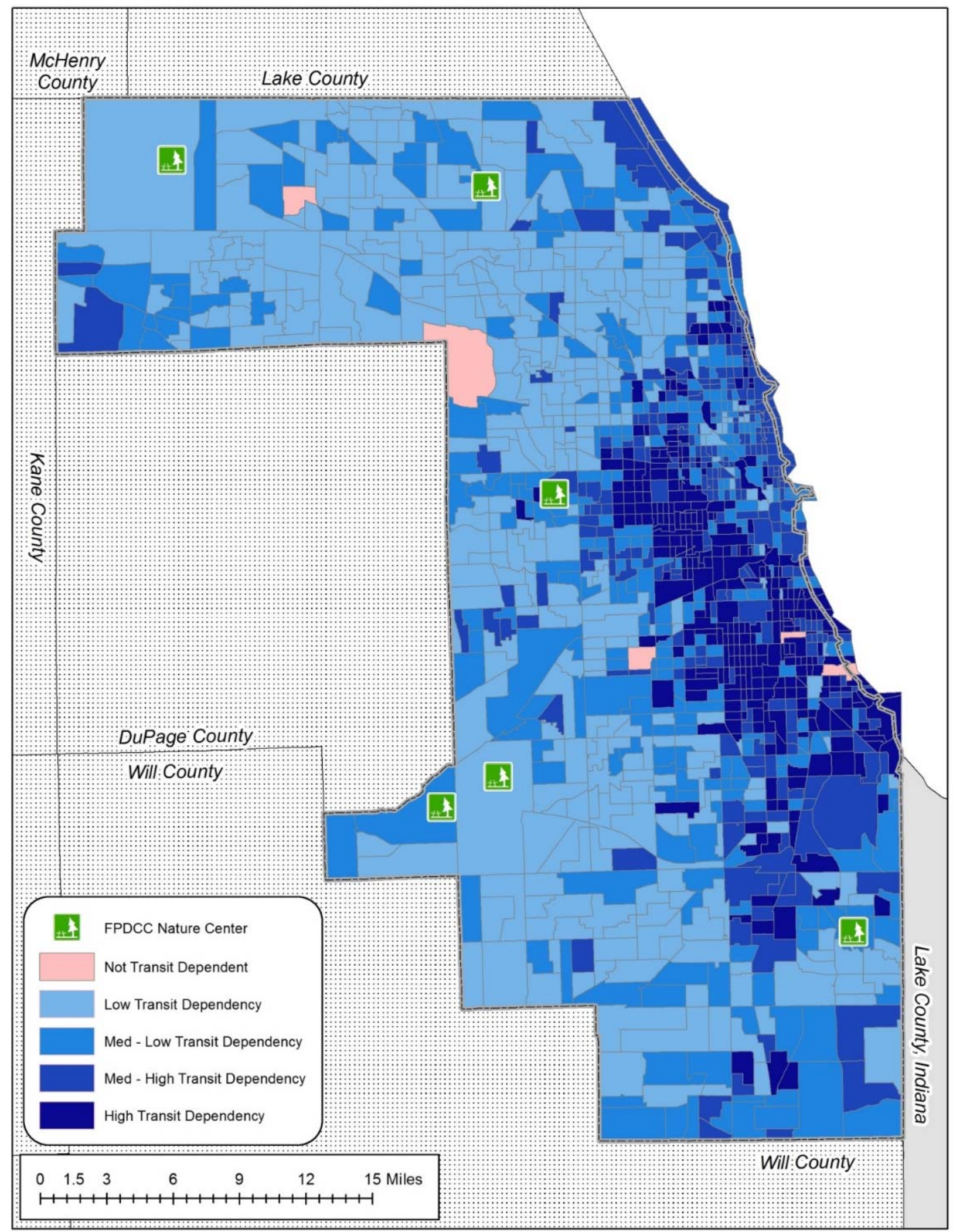


Figure 4: Zones of Maximum TD Criteria Met

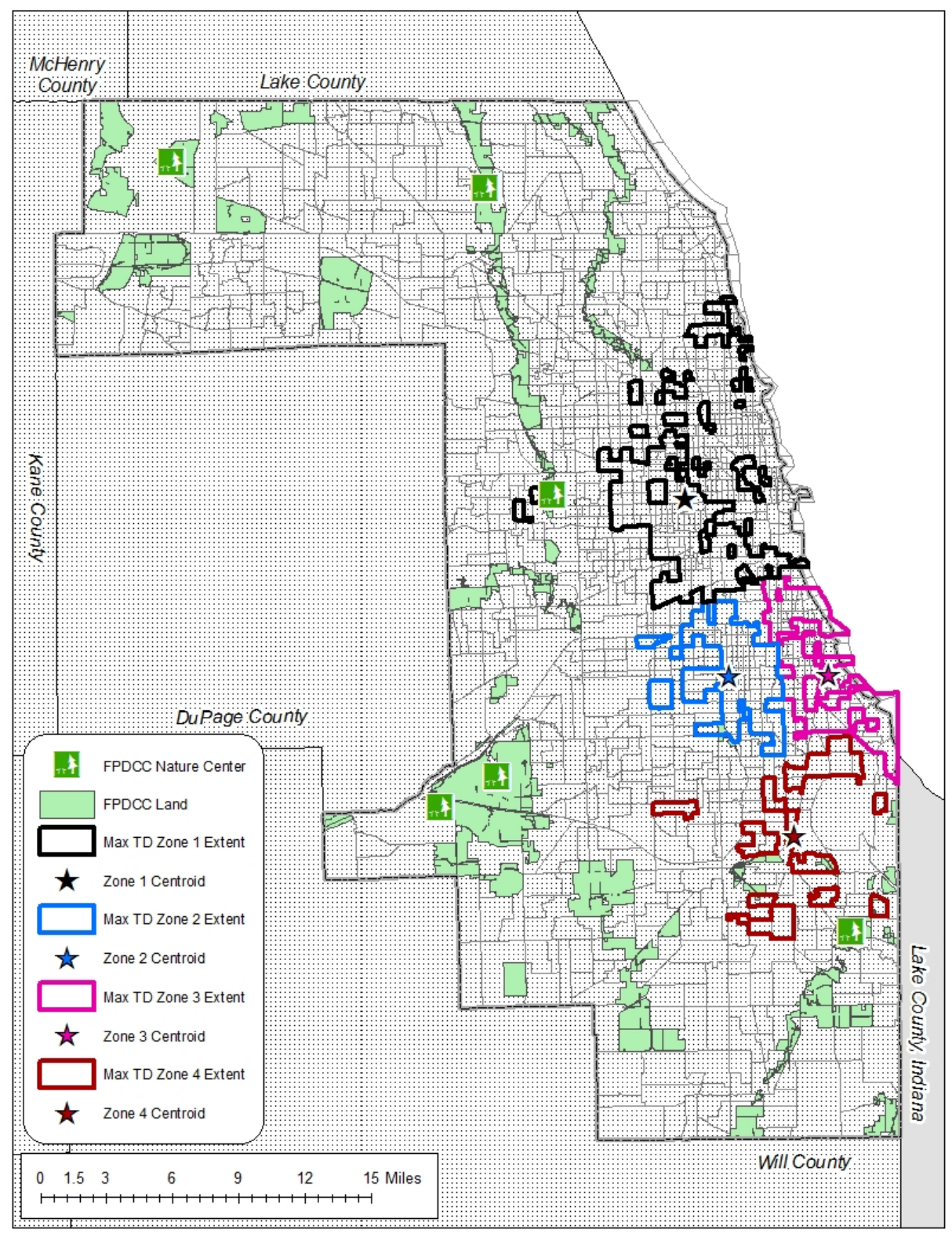

Max TD Zone 1 (Black)

Area: 35.92 sq miles

Approximate Centroid: 548 N Christiana Ave, Chicago

Max TD Zone 2 (Blue)

Area: 20.09 sq miles

Approximate Centroid: 6558 S Winchester Ave, Chicago

Max TD Zone 3 (Pink)

Area: 19.55 sq miles

Appoximate Centroid: 6651 S Stony Island Ave, Chicago

Max TD Zone 4 (Maroon)

Area: 15.12 sq miles

Approximate Centroid: 12351 S Indiana Ave, Chicago 


\subsection{Cook County Forest Preserve District Nature Centers}

The Forest Preserve District of Cook County operates six nature centers within the county with the general mission of interpreting nature itself to visitors. Activities are available for all age groups, from small children to adults. FPDCC nature centers do not focus on one particular activity but instead offer a variety of activities and programming and activities which often vary depending on the center in question.

FPDCC nature centers can be busy facilities (particularly on weekends), serving as a recreational destination to many residents of Cook County. Centers are kept staffed and are open during specific hours, which can fluctuate depending on the season. Some of the centers utilize historic buildings and facilities which have been adapted for their new use in educating the public about nature. Visitors can learn about not only the natural history of the region, but also local cultural history (topics such as Native Americans, early European settlements, and its early industries). Open year round, the centers have reduced hours during the winter but remain open (and may offer winter-specific activities, such as cross-country skiing, depending on the center).

All of the nature centers are located in suburban Cook County, outside of the city of Chicago. Two are located northwest of the city center, one directly west, two southwest, and one directly south. Presently, the simplest way to get to one of the nature centers (if not already within walking distance) is by automobile. Located on paved roads and with ample parking, this is how most visitors access the FPDCC nature centers. Transit is an option for direct access to some of the nature centers, although no specific provisions (special bus shelters, paved path between stop and nature center, etc) have been made by the County or local transit providers to encourage the use of transit in getting to and from any of the six nature centers. 
Figure 5: FPDCC Nature Center Locations

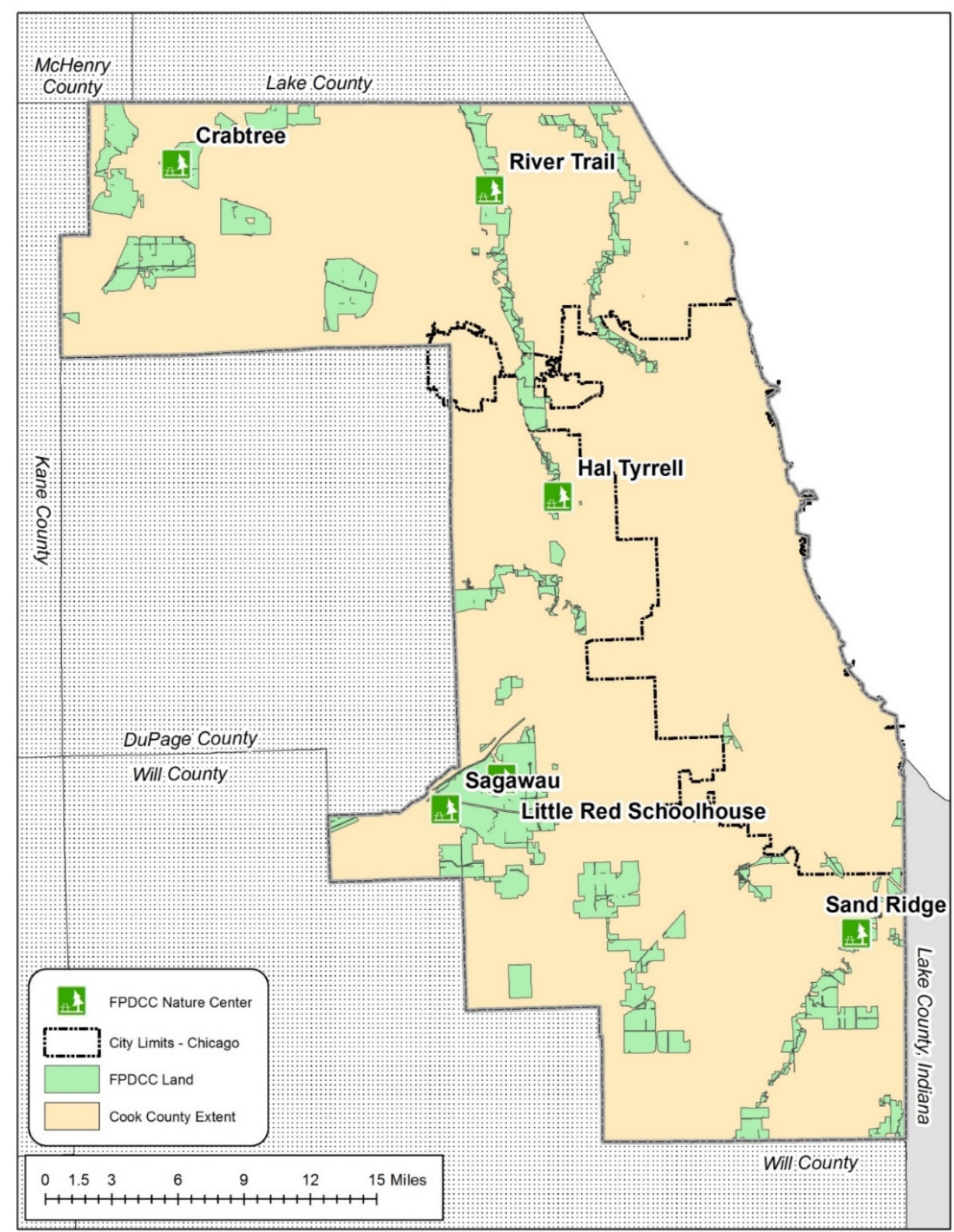

Per the above map, from North to South:

Crabtree Nature Center - 3 Stover Rd, Barrington Hills

River Trail Nature Center - 3120 Milwaukee Ave, Northbrook

Hal Tyrell Trailside Museum - 738 Thatcher Ave, River Forest

Little Red Schoolhouse Nature Center - 9800 Willow Springs Rd, Willow Springs

Sagawau Environmental Learning Center -12545 West $111^{\text {th }}$ St, Lemont

Sand Ridge Nature Center - 15891 Paxton Ave, South Holland 
Figure 6: Transit \& Roadways in Cook County

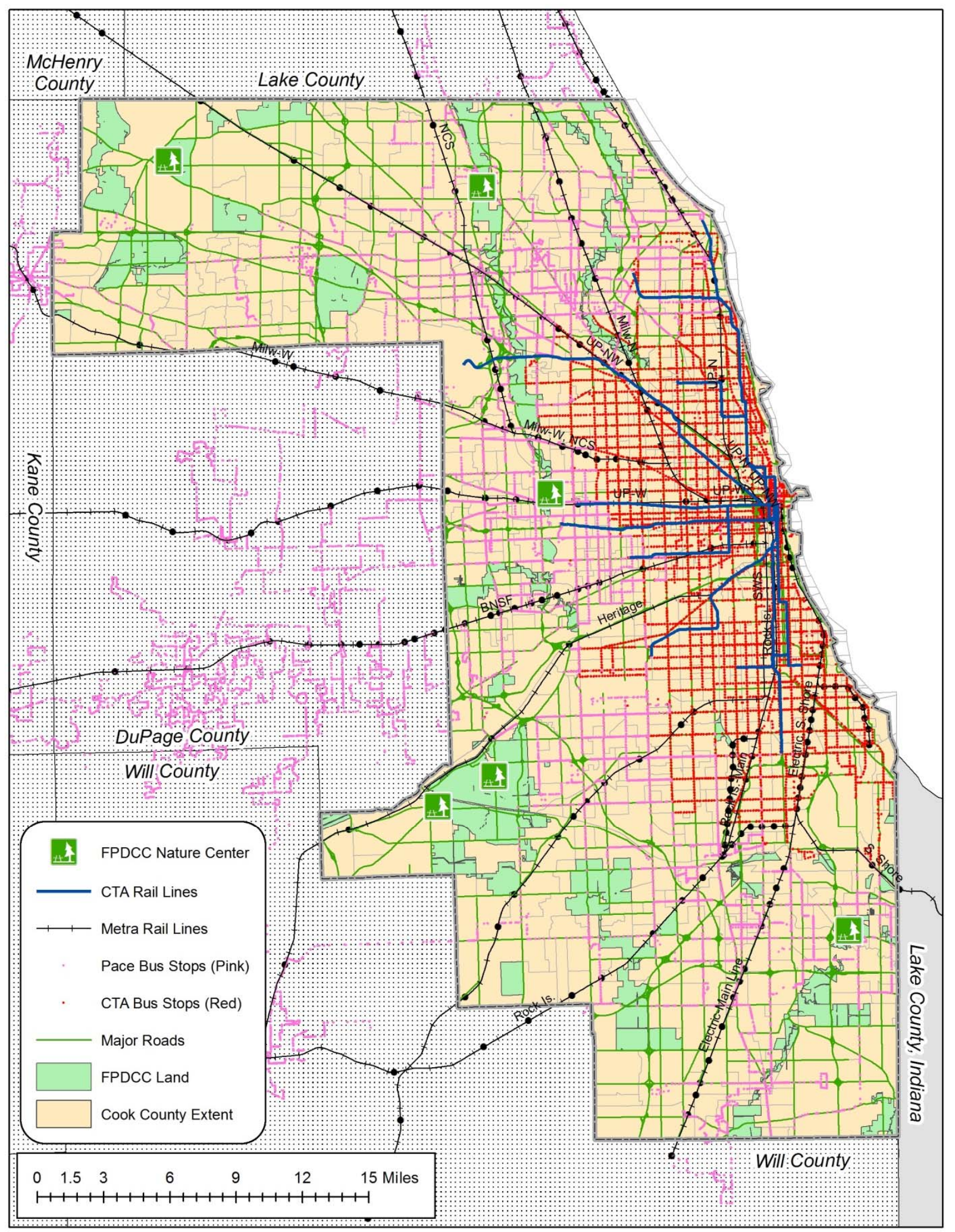


Displayed previously is a visualization of all transit and major roads within Cook County, as well as Cook County Forest Preserve District land and Nature Centers. Cook County is served by all four of the region's transit providers. The four transit providers are varied in their coverage of the region as a whole and how Cook County fits into their regional perspective:

\begin{tabular}{|c|r|r|r|}
\hline $\begin{array}{c}\text { Transit } \\
\text { Provider }\end{array}$ & $\begin{array}{r}\text { Provider's } \\
\text { Total Stops }\end{array}$ & $\begin{array}{c}\text { Cook } \\
\text { Stops }\end{array}$ & $\begin{array}{c}\text { \% of Total in } \\
\text { Cook }\end{array}$ \\
\hline CTA Bus & 11,273 & 11,273 & $100 \%$ \\
CTA Rail & 145 & 145 & $100 \%$ \\
Metra & 247 & 160 & $64.78 \%$ \\
Pace & 24,089 & 12,480 & $51.81 \%$ \\
\hline
\end{tabular}

Both CTA Bus and Rail service is entirely contained within Cook County. Metra also has a 65\% majority of its stops located within Cook County. Of the four providers, Pace has the least percentage of its stops located within Cook County; however, at $\sim 52 \%$, this is still a majority of the total and more than any other county. 
Figure 7: Bus Transit - FPDCC land within $1 / 4$ mile of CTA Bus \& Pace Stops

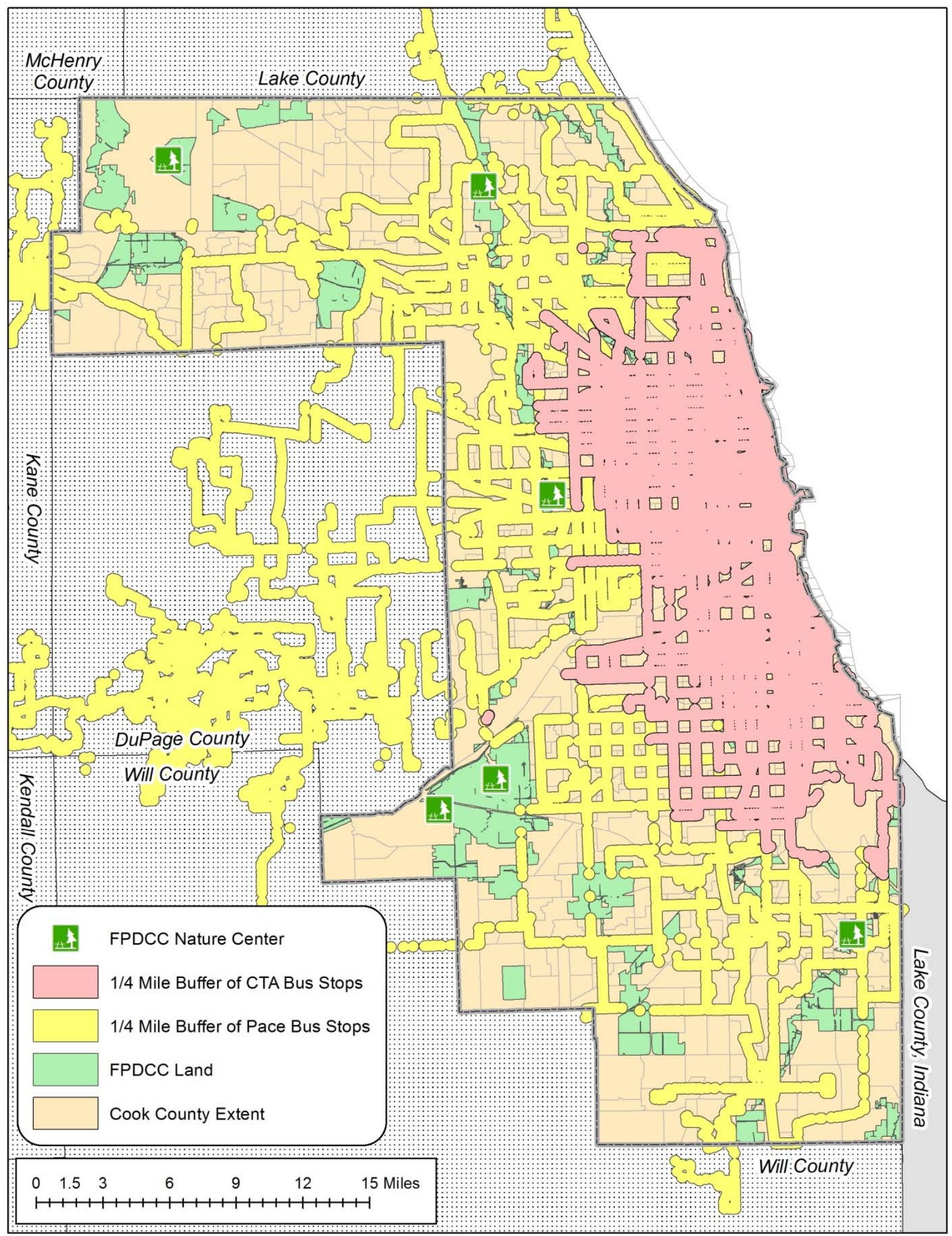


Figure 8: Rail Transit - FPDCC land within $1 / 2$ mile of CTA Rail \& Metra Stops

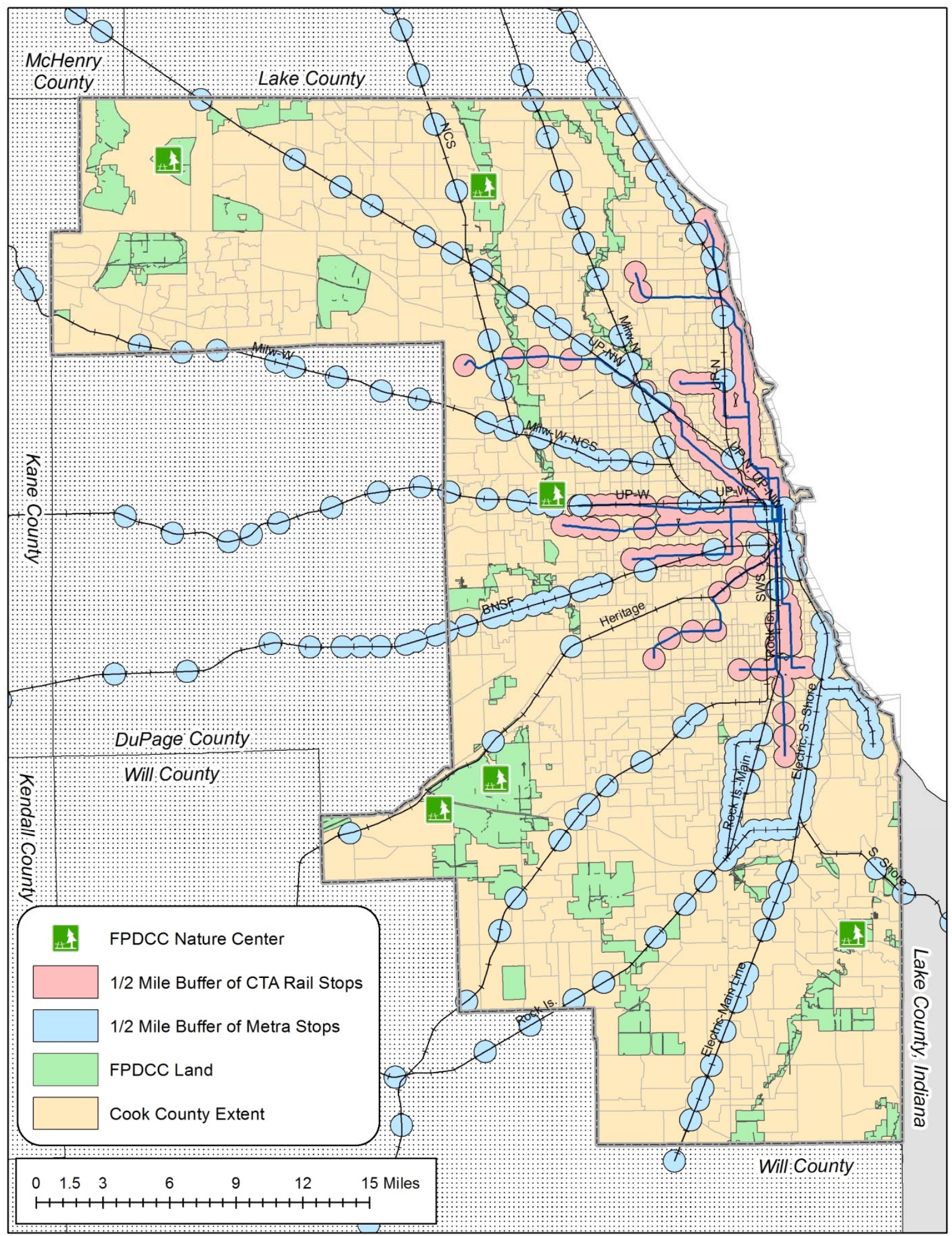


When predicting the maximum on-foot travel distance a potential rider of bus or rail transit rider is likely to travel in order to get to/from their chosen mode of transit, two different figures are typically used, depending on the mode: $1 / 4$ mile for bus transit, and $1 / 2$ mile for rail transit. The two previous maps display both bus and rail transit's direct proximity - within a $1 / 4$ or $1 / 2$ mile buffer, respectively - to FPDCC land, with the locations of its six Nature Centers also noted. Cook County's total square mileage of Forest Preserve District land accessible within a walk-able distance of CTA, Pace, and Metra stops is displayed in the table below:

\begin{tabular}{|c|c|}
\hline 1/4 Mile & Buffel \\
\hline CTA Bus & $\mathrm{Sq}$ \\
\hline Pace Bus & 16.38 Mi Sq \\
\hline
\end{tabular}

\begin{tabular}{|c|c|}
\hline $1 / 2 \mathrm{Mil}$ & 3uffer (Rail) \\
\hline CTA Rail & 0.3 \\
\hline Metra & 2.45 \\
\hline
\end{tabular}

Based on the above information, it's readily apparent that Pace's existing service is the leading provider of transit within a walking distance of FPDCC facilities, with over sixteen square miles of Forest Preserve District land falling within a walkable distance of Pace bus stops. Only around two square miles (each) of FPD land is within a walking distance of CTA Bus and Metra stops, and CTA Rail has the lowest walkable accessibility to FPD land - less than a half-square mile. What this can potentially translate to is possible usage of current Pace routes (streets equipped with stops, shelters, etc) and transit vehicles based at garages located respectively to each nature center.

\subsection{Preliminary Cook County Data}

Area of inhabited tracts within County: $971.92 \mathrm{mi}^{2}$

Number of inhabited tracts within County: 1318

Area of Environmental Justice tracts within County: $429.11 \mathrm{mi}^{2}$

Number of Environmental Justice tracts within County: 787

Percentage of County area which is Environmental Justice: $44.15 \%$

Percentage of County tracts which are Environmental Justice: $59.71 \%$

Area of Highly Transit Dependent tracts within County: $94.09 \mathrm{mi}^{2}$

Number of Highly Transit Dependent tracts within County: 340

Percentage of County area which is Highly Transit Dependent: $9.68 \%$

Percentage of Country tracts which are Transit Dependent: $18.7 \%$

Data Source: 2014 American Community Survey 5-year Estimates 


\subsection{Transit Availability and Accessibility to Nature Centers Using GTFS data}

First, General Transit Feed Specification (GTFS) data for the four major public transit providers serving Cook County was collected. These providers include: CTA (Bus and Rail), Pace, Metra, and NICTD. GIS shapefiles (year 2014 revisions, from the US Census Bureau) were then collected in two variants - first, roadway shapefiles were collected for all counties in Illinois, Indiana, and Wisconsin which are served by the four transit providers whose GTFS data was collected. Also collected was a year 2014 shapefile of census tracts in Cook County, along with associated census data tables respective to each census tract which allowed us to make the determination as to whether a given tract can be classified as an Environmental Justice area.

Using a specialized tool provided by ESRI (publisher of ArcGIS) as well as the Network Analyst extension of ArcGIS, service areas were then generated using the available GTFS data, as well as transit stop location data and roadway network data. Service area data was generated for 15, 30, 45, 60, and 90minute intervals. Using this data, we are able to overlay where service areas within the given time intervals can read EJ tracts within Cook County. To help provide a comparison, two different service areas were generated for each Nature Center - one reflecting transit service on a Saturday at 10:00 am, and one reflecting transit service on a Wednesday at 10:00 am. Two days (a weekday and weekend) were sampled in order to generate service areas more accurately, as weekday transit service tends to be more frequent and/or expansive than on weekends, but the FPDCC Nature Centers are more likely to be utilized by County residents on weekends. 


\begin{tabular}{|c|c|c|c|}
\hline \multicolumn{4}{|c|}{ Saturday, 10:00am } \\
\hline Site & Time & EJ Sq Mi Covered & \% Cty EJ Served \\
\hline \multirow{5}{*}{ Crabtree } & :15 & 0 & $0.00 \%$ \\
\hline & :30 & 0 & $0.00 \%$ \\
\hline & $: 45$ & 0 & $0.00 \%$ \\
\hline & $: 60$ & 0 & $0.00 \%$ \\
\hline & :90 & 0.03 & $0.01 \%$ \\
\hline \multirow{5}{*}{ Hal Tyrell } & :15 & 0.13 & $0.03 \%$ \\
\hline & $: 30$ & 1.48 & $0.34 \%$ \\
\hline & $: 45$ & 8.97 & $2.09 \%$ \\
\hline & $: 60$ & 35.67 & $8.31 \%$ \\
\hline & :90 & 103.41 & $24.10 \%$ \\
\hline \multirow{5}{*}{$\begin{array}{c}\text { Little Red } \\
\text { School } \\
\text { House }\end{array}$} & :15 & 0 & $0.00 \%$ \\
\hline & :30 & 0 & $0.00 \%$ \\
\hline & $: 45$ & 0 & $0.00 \%$ \\
\hline & $: 60$ & 0.03 & $0.01 \%$ \\
\hline & :90 & 3.37 & $0.79 \%$ \\
\hline \multirow{5}{*}{$\begin{array}{c}\text { River } \\
\text { Trail }\end{array}$} & :15 & 0.31 & $0.07 \%$ \\
\hline & :30 & 1.59 & $0.37 \%$ \\
\hline & $: 45$ & 3.92 & $0.91 \%$ \\
\hline & $: 60$ & 8.95 & $2.09 \%$ \\
\hline & :90 & 15.62 & $3.64 \%$ \\
\hline \multirow{5}{*}{ Sagawau } & :15 & 0 & $0.00 \%$ \\
\hline & :30 & 0 & $0.00 \%$ \\
\hline & $: 45$ & 0 & $0.00 \%$ \\
\hline & $: 60$ & 0 & $0.00 \%$ \\
\hline & :90 & 0 & $0.00 \%$ \\
\hline \multirow{5}{*}{$\begin{array}{l}\text { Sand } \\
\text { Ridge }\end{array}$} & :15 & 0.49 & $0.11 \%$ \\
\hline & :30 & 2.88 & $0.67 \%$ \\
\hline & $: 45$ & 9.44 & $2.20 \%$ \\
\hline & $: 60$ & 22.5 & $5.24 \%$ \\
\hline & :90 & 77.35 & $18.03 \%$ \\
\hline
\end{tabular}

\begin{tabular}{|c|c|c|c|}
\hline \multicolumn{4}{|c|}{ Wednesday, 10:00am } \\
\hline Site & Time & EJ Sq Mi Covered & $\%$ Cty EJ Served \\
\hline \multirow{5}{*}{ Crabtree } & :15 & 0 & $0.00 \%$ \\
\hline & :30 & 0 & $0.00 \%$ \\
\hline & $: 45$ & 0 & $0.00 \%$ \\
\hline & $: 60$ & 0 & $0.00 \%$ \\
\hline & :90 & 0.03 & $0.01 \%$ \\
\hline \multirow{5}{*}{ Hal Tyrell } & :15 & 0.13 & $0.03 \%$ \\
\hline & $: 30$ & 1.65 & $0.38 \%$ \\
\hline & $: 45$ & 14.76 & $3.44 \%$ \\
\hline & $: 60$ & 51.87 & $12.09 \%$ \\
\hline & :90 & 132.43 & $30.86 \%$ \\
\hline \multirow{5}{*}{$\begin{array}{c}\text { Little Red } \\
\text { School } \\
\text { House }\end{array}$} & :15 & 0 & $0.00 \%$ \\
\hline & :30 & 0 & $0.00 \%$ \\
\hline & $: 45$ & 0 & $0.00 \%$ \\
\hline & $: 60$ & 0.28 & $0.07 \%$ \\
\hline & :90 & 15.82 & $3.69 \%$ \\
\hline \multirow{5}{*}{$\begin{array}{c}\text { River } \\
\text { Trail }\end{array}$} & :15 & 0.31 & $0.07 \%$ \\
\hline & :30 & 1.59 & $0.37 \%$ \\
\hline & $: 45$ & 4.75 & $1.11 \%$ \\
\hline & $: 60$ & 9.99 & $2.33 \%$ \\
\hline & :90 & 16.18 & $3.77 \%$ \\
\hline \multirow{5}{*}{ Sagawau } & :15 & 0 & $0.00 \%$ \\
\hline & :30 & 0 & $0.00 \%$ \\
\hline & $: 45$ & 0 & $0.00 \%$ \\
\hline & $: 60$ & 0 & $0.00 \%$ \\
\hline & :90 & 0 & $0.00 \%$ \\
\hline \multirow{5}{*}{$\begin{array}{l}\text { Sand } \\
\text { Ridge }\end{array}$} & :15 & 0.49 & $0.11 \%$ \\
\hline & :30 & 3.85 & $0.90 \%$ \\
\hline & $: 45$ & 13.22 & $3.08 \%$ \\
\hline & $: 60$ & 28.63 & $6.67 \%$ \\
\hline & :90 & 112.16 & $26.14 \%$ \\
\hline
\end{tabular}

Using the above data table on 15-, 30-, 45-, 60- and 90-minute service areas surrounding the six Nature Centers, we can infer several things. The first is that the Sagawau Nature Center is not within ninety minutes of any census tract classified as EJ (on both weekdays and Saturdays). Similarly, the Crabtree Nature Center only contains 0.03 square miles of EJ tract area within its 90-minute service area (a figure applicable to both weekdays and Saturdays). Of the four remaining Nature Centers which are reasonably accessible via transit within a 90-minute service area, only Hal Tyrell, River Trail, and Sand Ridge are accessible to EJ tracts within the preferred 45-minute service area.

A large observation which can be made, however, is the fact that even the most expansive area served within the preferred maximum time window (45 minutes) covers only a minimal percentage of Cook County's total square mileage of Environmental Justice census tracts. The highest percentages of coverage belong to the Hal Tyrell and Sand Ridge Nature Centers; the former covering $2.09 \%$ on Saturdays and $3.44 \%$ on weekdays, and the latter covering $2.2 \%$ and $3.08 \%$, respectively. Even the best scenario (weekday coverage) leaves over $90 \%$ of the county's EJ area without transit access to any Nature Center within 45 minutes. 


\subsection{Location Summaries for FPDCC Nature Centers}

\subsection{Crabtree Nature Center}

Crabtree Nature Center is located on Stover Road in northwest suburban Barrington, $1 / 4$ mile north of the intersection of Palatine Rd and Stover. There is no sidewalk access along Stover or Palatine Roads leading to the nature center, and no transit stops within a $1 / 4$ and $1 / 2$ mile radius of the nature center itself.

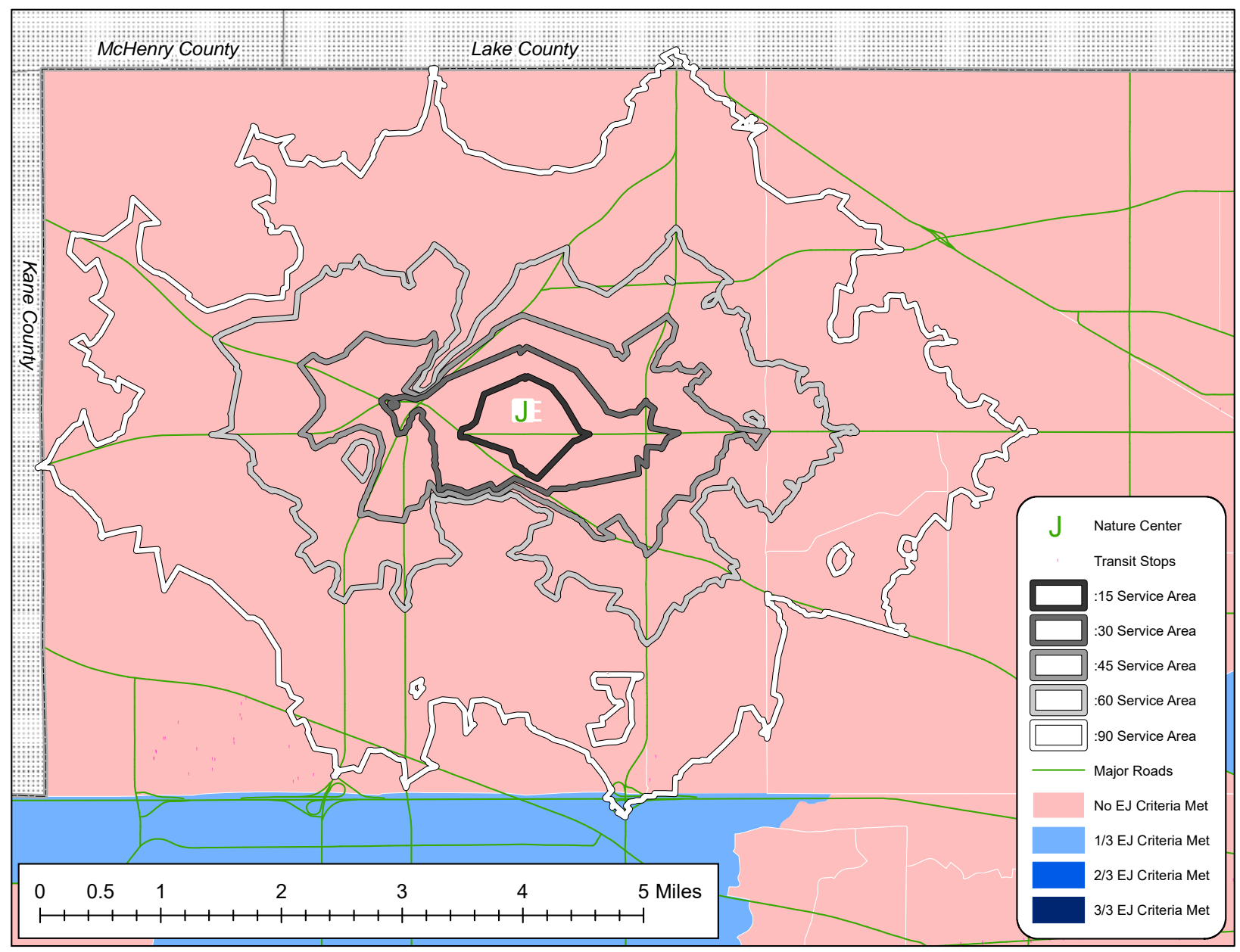

Figure 9: Crabtree 15, 30, 45, 60 \& 90-minute Transit Radius (Saturday \& Wednesday, 10:00a)

Although there is no transit access to Crabtree, an analysis was nonetheless performed in order to determine the "service area" surrounding it, from a strictly-pedestrian perspective [as currently utilized, the GIS software tool used for this analysis will calculate a walk time to/from transit stops nearest to the Nature Center, and then transit time. If no such transit stop is found, then the resulting service area is purely walk time.] The largest such service area - 90 minutes - lies almost completely within the county itself, and is located almost entirely within non-EJ census tracts. 
Saturdays, 10:00 am

Miles $^{2}$ of EJ Tracts Covered

Within 15 Minutes via Transit

\begin{tabular}{|c|c|c|}
$>50 \%$ Ethnic & $>50 \%$ Black & $>50 \%$ Lowlnc \\
0 & 0 & 0 \\
\hline
\end{tabular}

Within 30 Minutes via Transit

\begin{tabular}{|c|c|c|}
$>50 \%$ Ethnic & $>50 \%$ Black & $>50 \%$ Lowlnc \\
0 & 0 & 0 \\
\hline
\end{tabular}

Within 45 Minutes via Transit

\begin{tabular}{|c|c|c|}
$>50 \%$ Ethnic & $>50 \%$ Black & $>50 \%$ Lowlnc \\
0 & 0 & 0 \\
\hline
\end{tabular}

Within 60 Minutes via Transit

\begin{tabular}{|c|c|c|}
$>50 \%$ Ethnic & $>50 \%$ Black & $>50 \%$ Lowlnc \\
0 & 0 & 0 \\
\hline
\end{tabular}

Within 90 Minutes via Transit

\begin{tabular}{|c|c|c|}
$>50 \%$ Ethnic & $>50 \%$ Black & $>50 \%$ Lowlnc \\
0.03 & 0.03 & 0 \\
\hline
\end{tabular}
Wednesdays, 10:00 am

Miles $^{2}$ of EJ Tracts Covered

Within 15 Minutes via Transit

\begin{tabular}{|c|c|c|}
$>50 \%$ Ethnic & $>50 \%$ Black & $>50 \%$ Lowlnc \\
0 & 0 & 0 \\
\hline
\end{tabular}

Within 30 Minutes via Transit

\begin{tabular}{|c|c|c|}
$>50 \%$ Ethnic & $>50 \%$ Black & $>50 \%$ Lowlnc \\
0 & 0 & 0 \\
\hline
\end{tabular}

Within 45 Minutes via Transit

\begin{tabular}{|c|c|c|}
$>50 \%$ Ethnic & $>50 \%$ Black & $>50 \%$ Lowlnc \\
0 & 0 & 0 \\
\hline
\end{tabular}

Within 60 Minutes via Transit

\begin{tabular}{|c|c|c|}
$>50 \%$ Ethnic & $>50 \%$ Black & $>50 \%$ Lowlnc \\
0 & 0 & 0 \\
\hline
\end{tabular}

Within 90 Minutes via Transit

\begin{tabular}{|c|c|c|}
$>50 \%$ Ethnic & $>50 \%$ Black & $>50 \%$ Lowlnc \\
0.03 & 0.03 & 0 \\
\hline
\end{tabular}

As the above tables indicate, only a very small geographical area with EJ characteristics is within a 90minute service area of the Crabtree nature center. Given the lack of currently-available transit options within close proximity to Crabtree, and few EJ tracts near the Center itself, this Nature Center is not an ideal choice to be the destination of any Nature Express service.

\subsection{River Trail Nature Center}

River Trail is located in north suburban Northbrook, south of the intersection of Milwaukee Avenue and River Road. River Trail Nature Center has four Pace bus stops within $1 / 4$ mile of its main entrance. Within $1 / 2$ mile of its main entrance, there are two additional Pace bus stops. From the main entrance to River Trail on Milwaukee Avenue, there is no sidewalk access to the nature center itself.

Hours: 9:00a-4:30p (summer; close at 3:30p in colder months)

\begin{tabular}{|c|c|c|c|c|c|}
\hline \multicolumn{4}{|c|}{ River Trail Stops } \\
\hline \multicolumn{3}{|c|}{ 1/4 Mile } & \multicolumn{4}{c|}{ 1/2 Mile } \\
Provider & Stops & Routes & Provider & Stops & Routes \\
\hline Pace Bus & 4 & 4 & Pace Bus & 6 & 5 \\
\hline
\end{tabular}

\begin{tabular}{|l|l|l|l|}
\hline \multicolumn{4}{|c|}{ River Trail Routes within 1/2 Mile } \\
\hline Route & M-F? & Sat? & Sun? \\
\hline Pace 270 & Y & Y & Y \\
Pace 272 & Y & Y & N \\
Pace 619 & Y & N & N \\
Pace 620 & Y & N & N \\
Pace 623 & Y & N & N \\
\hline
\end{tabular}




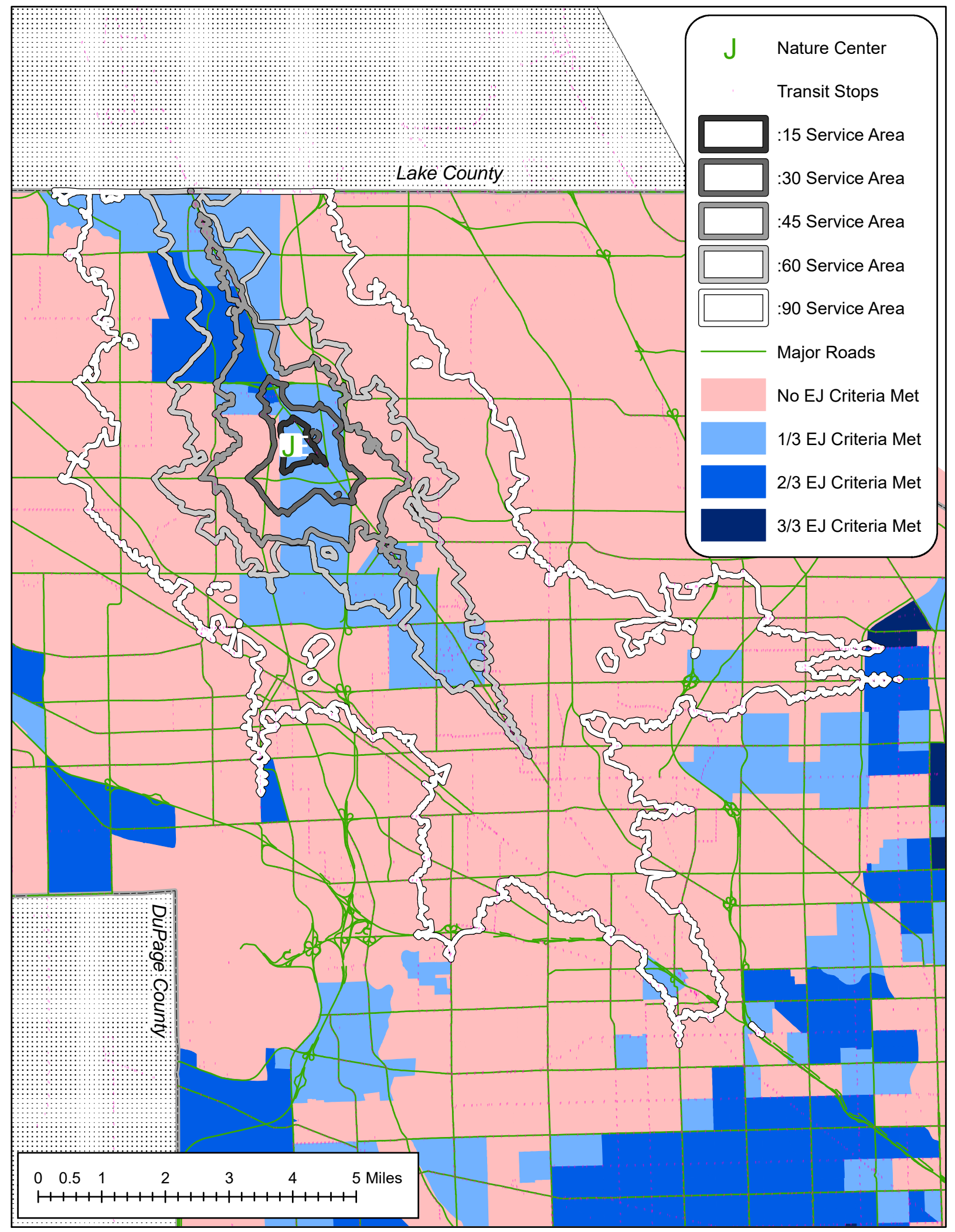

Figure 10: River Trail 15, 30, 45, 60 \& 90-minute Transit Radius (Saturday, 10:00a) 


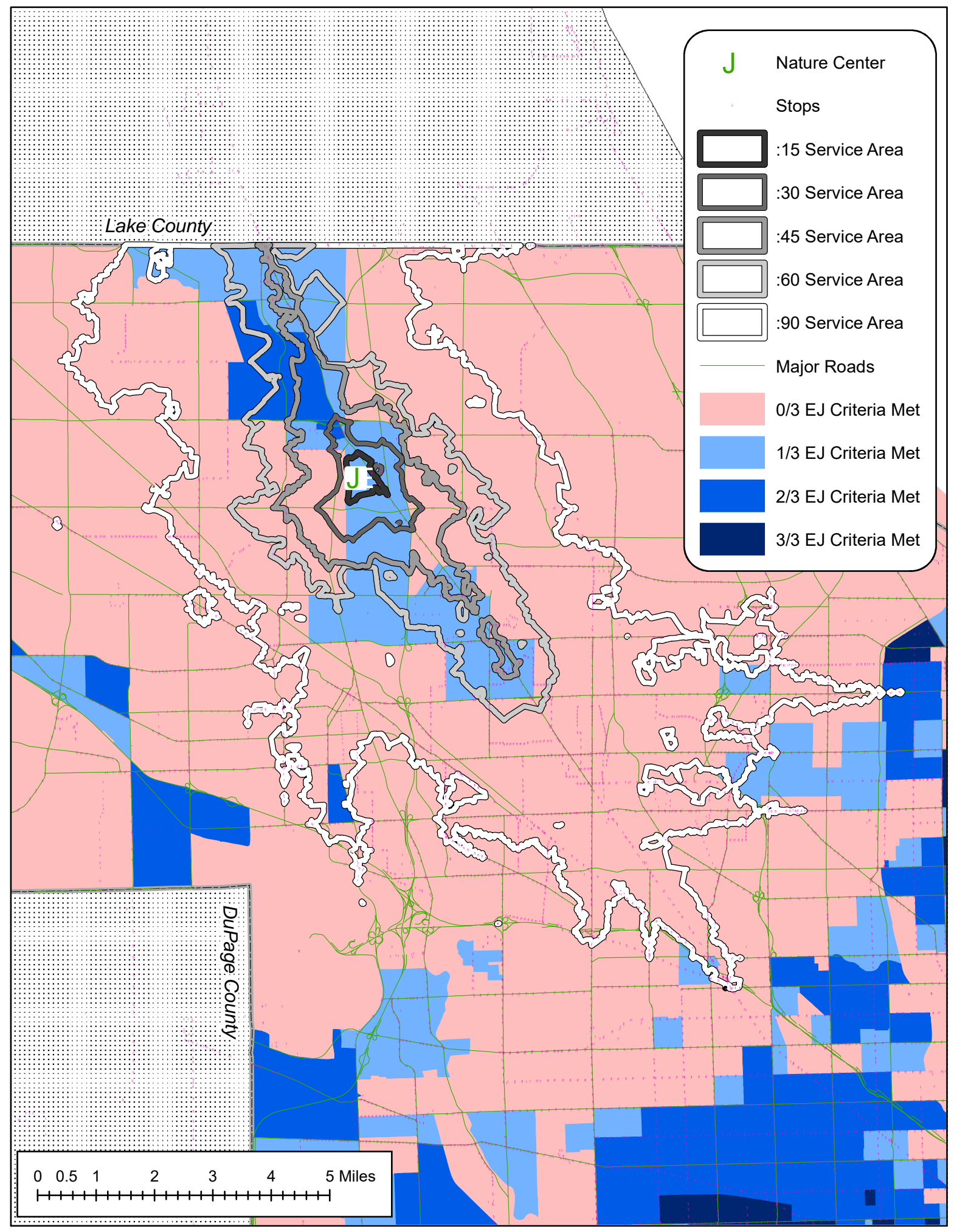

Figure 11: River Trail 15, 30, 45, 60 \& 90-minute Transit Radius (Wednesday, 10:00a) 

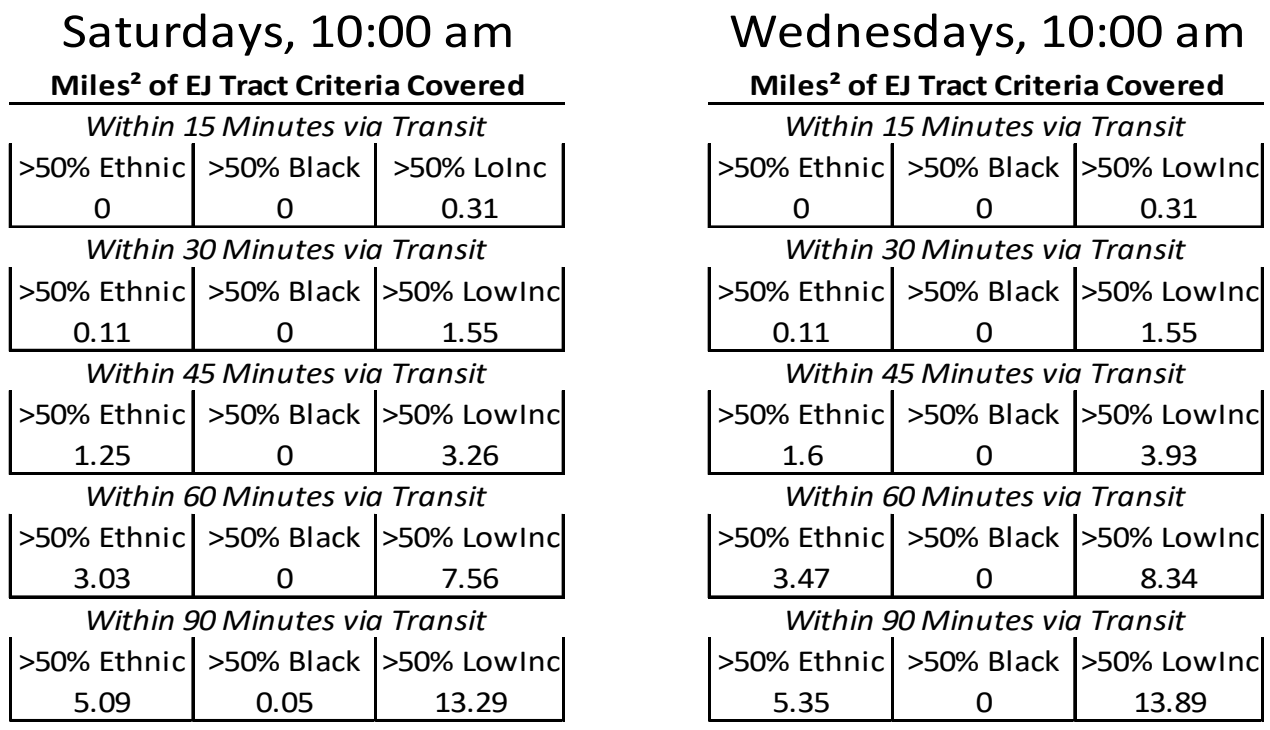

As a facility served by a Nature Express-type of service, River Trail has limited potential. While the Nature Center is not totally inaccessible from EJ tracts within the preferred 45-minute service area, the closest service areas we analyzed (15- and 30-minutes) served only a very small area of EJ tracts - less than two square miles for both Saturday and weekday service. Overall, the most glaring issue with River Trail's service areas is that even in the longer 60- and 90-minute service areas, the EJ areas classified as having a $>50 \%$ black population are almost completely absent from the resulting served geography. While River Trail's analysis does result in some EJ tracts being within the 15- to 90-minute service areas which were specified, the type of EJ tracts being served is unevenly distributed. More investigation is required to determine if it is possible to create new (or modify existing) transit routes which will better serve a more balanced grouping of the three types of EJ tracts.

\subsection{Hal Tyrrell Trailside Museum}

The Trailside Museum is located on the southwest corner of Chicago Avenue and Thatcher Avenue in west suburban River Forest. It has no transit stops within a $1 / 4$ mile radius. Within a $1 / 2$ mile radius, there are four Pace bus stops, and one Metra stop (River Forest on the UP-W line). The Trailside Museum is the only FPDCC Nature Center with sidewalk access.

\begin{tabular}{|l|c|c|}
\hline \multicolumn{3}{|c|}{ Trailside Stops } \\
\hline \multicolumn{3}{|c|}{ 1/2 Mile } \\
Provider & Stops & Routes \\
\hline Pace & 4 & 3 \\
Metra & 1 & 1 \\
\hline
\end{tabular}

\begin{tabular}{|c|c|c|c|}
\hline \multicolumn{4}{|c|}{ Trailside Routes within 1/2 Mile } \\
\hline Route & M-F? & Sat? & Sun? \\
\hline Pace 305 & Y & Y & Y \\
Pace 309 & Y & Y & Y \\
Pace 313 & Y & Y & Y \\
Metra UP-W & Y & Y & Y \\
\hline
\end{tabular}




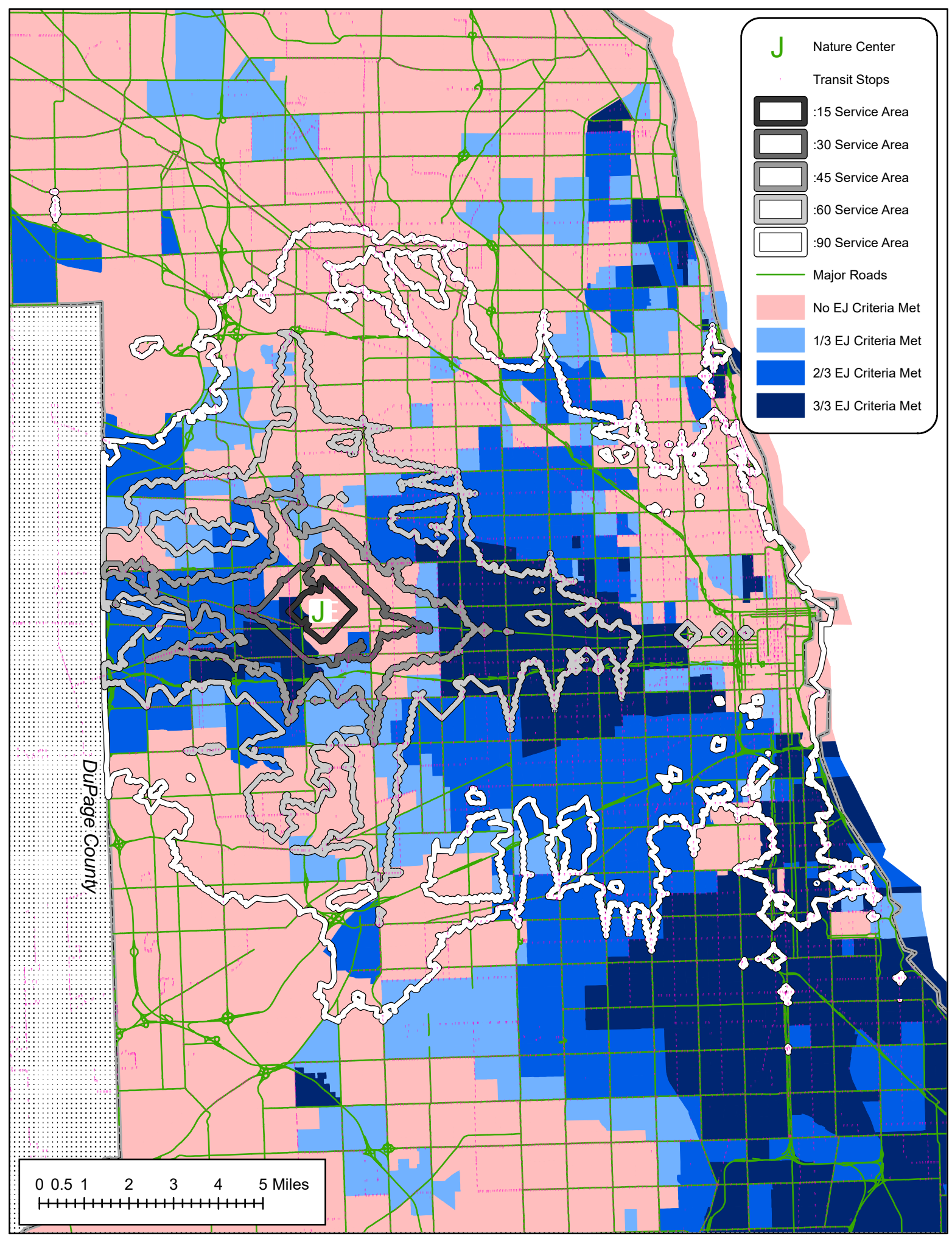

Figure 12: Trailside Museum 15, 30, 45, 60 \& 90-minute Transit Radius (Saturday, 10:00a) 


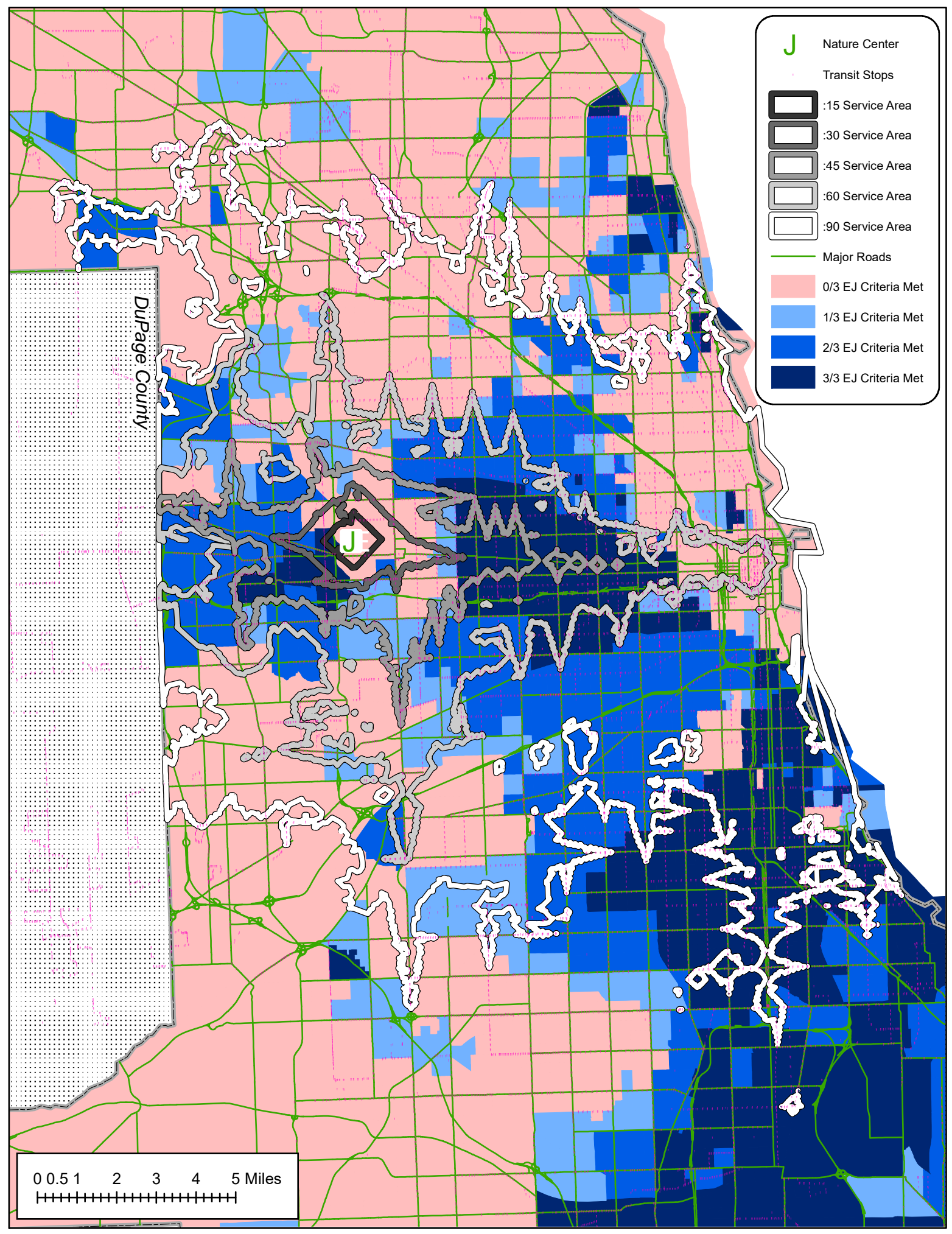

Figure 13: Trailside Museum 15, 30, 45, 60 \& 90-minute Transit Radius (Wednesday, 10:00a) 


\begin{tabular}{|c|c|c|}
\hline \multicolumn{3}{|c|}{$\begin{array}{l}\text { Saturdays, 10:00 am } \\
\text { Miles }^{2} \text { of EJ Tract Criteria Covered }\end{array}$} \\
\hline \multicolumn{3}{|c|}{ Within 15 Minutes via Transit } \\
\hline$>50 \%$ Ethnic & | >50\% Black & $>50 \%$ Lolnc \\
\hline 0.13 & 0.13 & 0.13 \\
\hline \multicolumn{3}{|c|}{ Within 30 Minutes via Transit } \\
\hline$>50 \%$ Ethnic & $>50 \%$ Black & $>50 \%$ Lowlnc \\
\hline 1.28 & 1.19 & 1.08 \\
\hline \multicolumn{3}{|c|}{ Within 45 Minutes via Transit } \\
\hline$>50 \%$ Ethnic & $>50 \%$ Black & $>50 \%$ Lowlnc \\
\hline 6.74 & 6.05 & 5.99 \\
\hline \multicolumn{3}{|c|}{ Within 60 Minutes via Transit } \\
\hline$>50 \%$ Ethnic & $>50 \%$ Black & $>50 \%$ Lowlnc \\
\hline 28.5 & 23.72 & 22.45 \\
\hline \multicolumn{3}{|c|}{ Within 90 Minutes via Transit } \\
\hline$>50 \%$ Ethnic & $>50 \%$ Black & $>50 \%$ Lowlnc \\
\hline 86.79 & 45.39 & 77.23 \\
\hline
\end{tabular}

\begin{tabular}{|c|c|c|}
\hline \multicolumn{3}{|c|}{$\begin{array}{c}\text { Wednesdays, 10:00 am } \\
\text { Miles }^{2} \text { of EJ Tract Criteria Covered }\end{array}$} \\
\hline \multicolumn{3}{|c|}{ Within 15 Minutes via Transit } \\
\hline 0\% Ethnic & $>50^{\circ}$ & $\mid>50 \%$ \\
\hline - & & 0.1 \\
\hline \multicolumn{3}{|c|}{ Within 30 Minutes via Transit } \\
\hline $50 \%$ Ethnic & & $>50 \%$ Lo \\
\hline & & 1.2 \\
\hline \multicolumn{3}{|c|}{ Within 45 Minutes via Transit } \\
\hline $50 \%$ Ethnic & $>50 \%$ Black & $>50 \%$ Lowlnc \\
\hline S & & 9.19 \\
\hline \multicolumn{3}{|c|}{ Within 60 Minutes via Transit } \\
\hline $50 \%$ Ethnic & $>50 \%$ Black & $>50 \%$ Lowlnc \\
\hline 42.7 & 29.99 & 35.43 \\
\hline \multicolumn{3}{|c|}{ Within 90 Minutes via Transit } \\
\hline $50 \%$ Ethnic & lack & $>50 \%$ Lo \\
\hline 110.71 & & 102. \\
\hline
\end{tabular}

Although the square mileage of EJ tracts (under all three criteria) is minimal in the 15-minute service area analysis (for both Saturday and weekdays), Hal Tyrell shows more potential in the 30-minute (and greater) service areas. These service areas are aided largely by Pace's west suburban operations as well as Metra's UP-West line. While the census tracts immediately surrounding the Nature Center itself are not classified as EJ by any of the three measures, significant pockets of EJ tracts exist to its east and west. Nature Express service implemented with a focus on these two areas would be an ideal way to take advantage of Hal Tyrell's location.

\subsection{Little Red Schoolhouse Nature Center}

The Little Red Schoolhouse complex is located south of $95^{\text {th }}$ Street on Flavin Road in southwest suburban Willow Springs. It is a short distance northeast of the Sagawau Environmental Learning Center (approximately four miles via road). Within a $1 / 4$ and $1 / 2$ mile radii, there are no transit stops near the Little Red Schoolhouse. There is no sidewalk access to the center via Flavin Road.

Hours: 9:00a-4:30p (summer; close at 3:30p in colder months) 


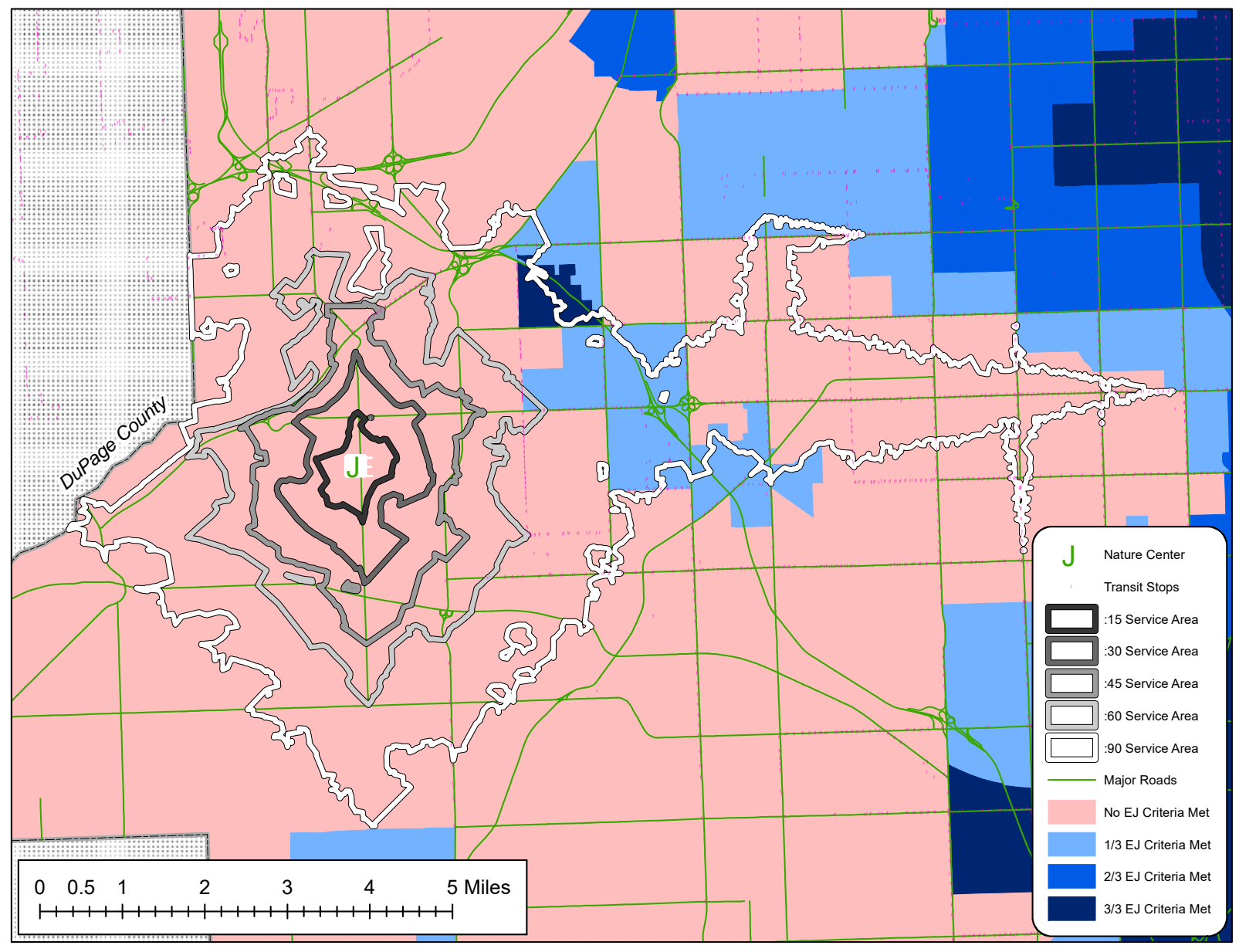

Figure 14: Little Red Schoolhouse 15, 30, 45, 60 \& 90-minute Transit Radius (Saturday, 10:00a) 


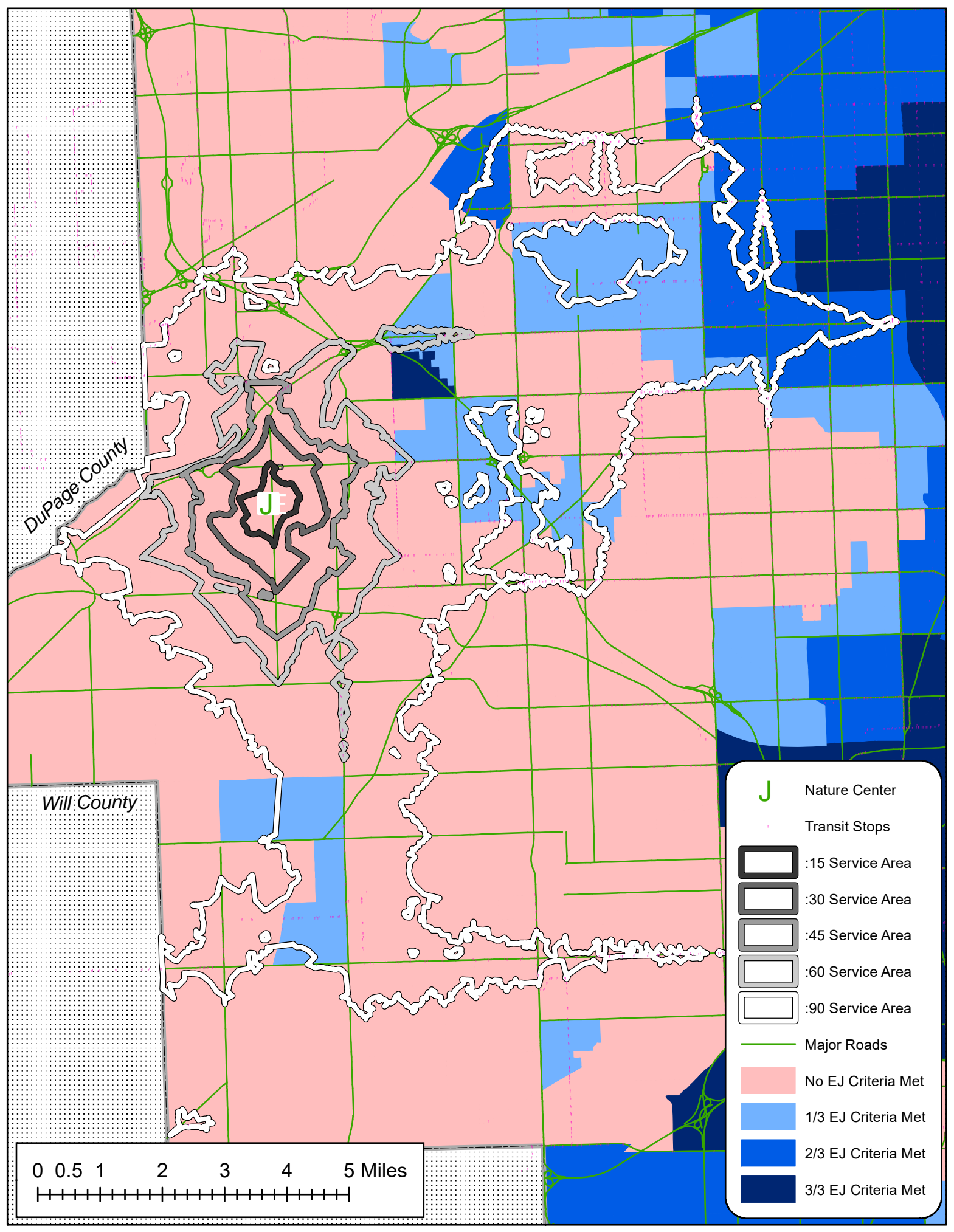

Figure 15: Little Red Schoolhouse 15, 30, 45, 60 \& 90-minute Transit Radius (Wednesday, 10:00a) 


\begin{tabular}{c} 
Saturdays, $10: 00$ a m \\
Miles $^{2}$ of EJ Tract Criteria Covered \\
\hline Within 15 Minutes via Transit \\
\begin{tabular}{|c|c|c|}
$>50 \%$ Ethnic & $>50 \%$ Black & $>50 \%$ Lolnc \\
0 & 0 & 0 \\
\hline
\end{tabular}
\end{tabular}

Within 30 Minutes via Transit $\mid>50 \%$ Ethnic $\mid>50 \%$ Black |>50\% Low Inc \begin{tabular}{l|c|c}
0 & 0 & 0 \\
\hline
\end{tabular}

Within 45 Minutes via Transit \begin{tabular}{|c|c|c|}
$>50 \%$ Ethnic & $>50 \%$ Black & $>50 \%$ Low Inc \\
0 & 0 & 0 \\
\hline
\end{tabular}

Within 60 Minutes via Transit

\begin{tabular}{|c|c|c|}
$>50 \%$ Ethnic & $>50 \%$ Black & $>50 \%$ Low Inc \\
0 & 0 & 0.01 \\
\hline
\end{tabular}

With in 90 Minutes via Transit $\mid>50 \%$ Ethnic $\mid>50 \%$ Black $\mid>50 \%$ Low Inc
Wednesdays, 10:00 am

Miles $^{2}$ of EJ Tract Criteria Covered

With in 15 Minutes via Transit

\begin{tabular}{|c|c|c|}
$>50 \%$ Ethnic & $>50 \%$ Black & $>50 \%$ Low Inc \\
0 & 0 & 0 \\
\hline
\end{tabular}

Within 30 Minutes via Transit

$\mid>50 \%$ Ethnic $\mid>50 \%$ Black $\mid>50 \%$ Low Inc

With in 45 Minutes via Transit

\begin{tabular}{|c|c|c|}
$>50 \%$ Ethnic & $>50 \%$ Black & $>50 \%$ Low Inc \\
0 & 0 & 0 \\
\hline
\end{tabular}

With in 60 Minutes via Transit

$\mid>50 \%$ Ethnic $\mid>50 \%$ Black $\mid>50 \%$ Low Inc

\begin{tabular}{l|l|l}
0.1 & 0.1 & 0.29 \\
\hline
\end{tabular}

With in 90 Minutes via Transit

\begin{tabular}{|c|c|c|}
$>50 \%$ Ethnic & $>50 \%$ Black & $>50 \%$ Low Inc \\
5.53 & 1.57 & 3.98 \\
\hline
\end{tabular}

Because the Little Red Schoolhouse has no transit stops within a $1 / 4$ and $1 / 2$ mile radius, the service areas indicated for the 15- through 45-minute time intervals are actually for a hypothetical pedestrian, as the tool used generates space using a walking speed when transit is not available. However, transit is "found" in the 60- and 90-minute intervals, as we find some EJ tract coverage brought upon by the existence of transit stops (Pace Bus) within said service areas. A potential visitor would access the Little Red Schoolhouse by simply walking there from one of these stops (calculated to take at least 45 minutes, since the nearest stops are within the 60-minute service area).

It would be challenging to provide Nature Express service to the Little Red Schoolhouse. In addition to a lack of transit near the nature center itself, there are also very few EJ tracts in the areas around it; however, tracts meeting multiple criteria of EJ are located just outside of the largest (90-minute) service area. While the Little Red Schoolhouse can serve some EJ tracts within a 90-minute travel distance, this is highly unlikely given the amount of walking required. The best solution for providing Nature Express service to the Little Red Schoolhouse may be a weekend-only shuttle, with limited stops in areas with a high degree of EJ and terminating at the Schoolhouse itself.

\subsection{Sand Ridge Nature Center}

Sand Ridge is located just north of $159^{\text {th }}$ Street on Paxton Avenue in south suburban Calumet City. There are no transit stops within a $1 / 4$ mile radius of the nature center's entrance. Within a $1 / 2$ mile radius, there are two Pace bus stops. Sand Ridge does not have sidewalk access via Paxton Avenue.

\begin{tabular}{|l|c|c|}
\hline \multicolumn{3}{|c|}{ Sand Ridge Stops } \\
\hline \multicolumn{3}{|c|}{$1 / 2$ Mile } \\
Provider & Stops & Routes \\
\hline Pace & 2 & 1 \\
\hline
\end{tabular}

\begin{tabular}{|c|c|c|c|}
\hline \multicolumn{4}{|c|}{ Sand Ridge Routes within 1/2 Mile } \\
\hline Route & M-F? & Sat? & Sun? \\
\hline Pace 364 & Y & Y & Y \\
\hline
\end{tabular}




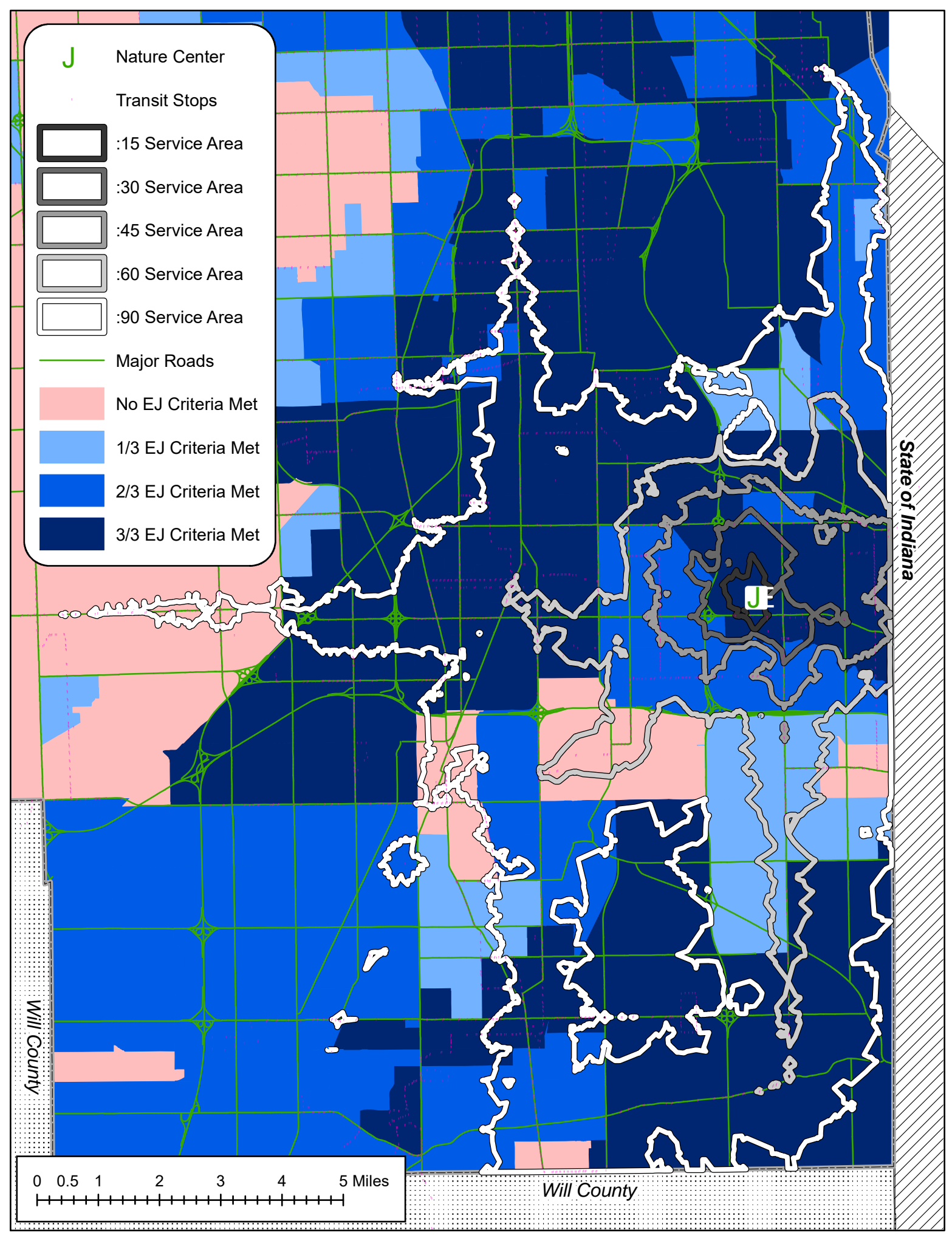

Figure 16: Sand Ridge 15, 30, 45, 60 \& 90-minute Transit Radius (Saturday, 10:00a) 


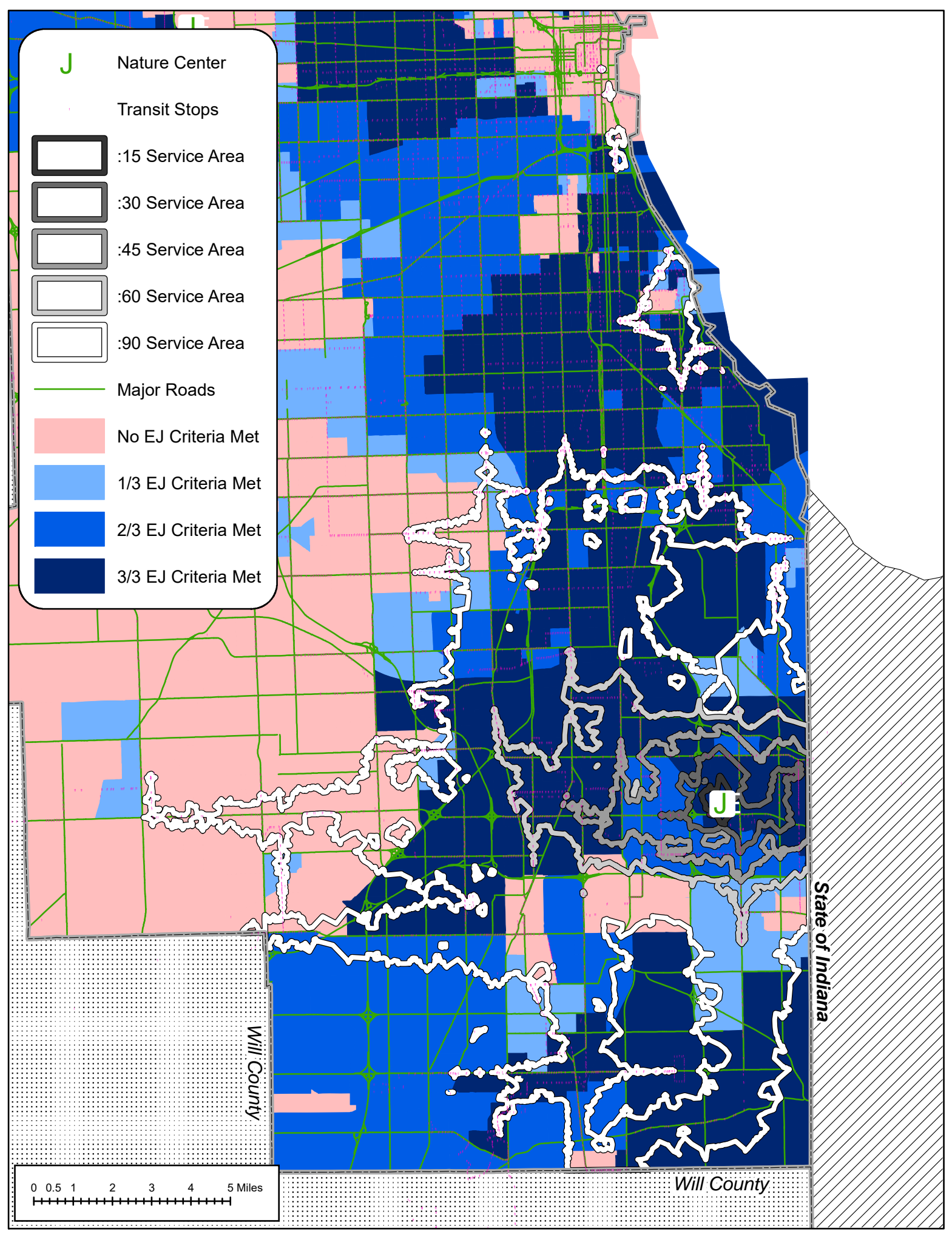

Figure 17: Sand Ridge 15, 30, 45, 60 \& 90-minute Transit Radius (Wednesday, 10:00a) 


\begin{tabular}{|c|c|c|}
\hline \multicolumn{3}{|c|}{$\begin{array}{l}\text { Saturdays, 10:00 am } \\
\text { Miles }^{2} \text { of EJ Tract Criteria Covered }\end{array}$} \\
\hline \multicolumn{3}{|c|}{ Within 15 Minutes via Transit } \\
\hline$>50 \%$ Ethnic & $>50 \%$ Black & $>50 \%$ Lolnc \\
\hline 0.49 & 0.49 & 0.49 \\
\hline \multicolumn{3}{|c|}{ Within 30 Minutes via Transit } \\
\hline$>50 \%$ Ethnic & $>50 \%$ Black & $>50 \%$ Lowlnd \\
\hline 2.88 & 2.88 & 2.49 \\
\hline \multicolumn{3}{|c|}{ Within 45 Minutes via Transit } \\
\hline$>50 \%$ Ethnic & $>50 \%$ Black & $>50 \%$ Lowlnc \\
\hline 9.44 & 9.44 & 6.56 \\
\hline \multicolumn{3}{|c|}{ Within 60 Minutes via Transit } \\
\hline$>50 \%$ Ethnic & $>50 \%$ Black & $>50 \%$ Lowlnd \\
\hline 19.88 & 22.19 & 11.93 \\
\hline \multicolumn{3}{|c|}{ Within 90 Minutes via Transit } \\
\hline$>50 \%$ Ethnic & $>50 \%$ Black & $>50 \%$ Lowlnc \\
\hline 68.44 & 68.77 & 52.56 \\
\hline
\end{tabular}

\begin{tabular}{|c|c|c|}
\hline \multicolumn{3}{|c|}{$\begin{array}{c}\text { Wednesdays, } 10: 00 \text { am } \\
\text { Miles }^{2} \text { of Es Tract Criteria Covered }\end{array}$} \\
\hline \multicolumn{3}{|c|}{ Within 15 Minutes via Transit } \\
\hline$>50 \%$ Ethnic & $>50 \%$ Black & $>50 \%$ Lo \\
\hline 0.49 & 0.49 & 0.49 \\
\hline \multicolumn{3}{|c|}{ Within 30 Minutes via Transit } \\
\hline$>50 \%$ Ethnic & $>50 \%$ Black & $>50 \%$ Lowlnc \\
\hline 3.85 & 3.85 & 3.34 \\
\hline \multicolumn{3}{|c|}{ Within 45 Minutes via Transit } \\
\hline$>50 \%$ Ethnic & $>50 \%$ Black & $>50 \%$ Lowlnc \\
\hline 13.2 & 13.22 & 8.19 \\
\hline \multicolumn{3}{|c|}{ Within 60 Minutes via Transit } \\
\hline$>50 \%$ Ethnic & $>50 \%$ Black & $>50 \%$ Lowlnc \\
\hline 27.73 & 28.63 & 19.23 \\
\hline \multicolumn{3}{|c|}{ Within 90 Minutes via Transit } \\
\hline >50\% Ethnic & $>50 \%$ Black & |>50\% Lowlnc \\
\hline 101.25 & 104.83 & 78.74 \\
\hline
\end{tabular}

While the 15-minute service area immediately surrounding Sand Ridge yeilds only about a half squaremile of EJ area (under all three criteria), the 30-minute and (and greater) service areas offer progressively greater numbers which would make Sand Ridge the best candidate for the easiest implementation of Nature Express service. Bearing in mind that the given square mileage of EJ tracts (on the above table) within a 45-minute service area may seem small, these are actually the highest of such numbers found in our analysis of all six Nature Centers. While new transit service provided specifically with the intent of providing access to Nature Centers from EJ tracts will increase access to any of the six Nature Centers, Sand Ridge is likely the best Center to be accessed from EJ tracts using regularlyscheduled transit routes. Minor adjustments made to existing schedules or routes may also increase the reach of transit to EJ tracts within the preferred 45-minute service area.

\subsection{Sagawau Environmental Learning Center}

Sagawau is located at the intersection of IL Route 83 and Archer Avenue, off of Route 83. It is southwest of the nearby Little Red Schoolhouse Nature Center. There are no transit stops within a $1 / 4$ or $1 / 2$ mile radius of Sagawau. There is no sidewalk access to Sagawau via Route 83. In 2015, the Cal-Sag Trail was opened, which has its western terminus at Sagawau. 


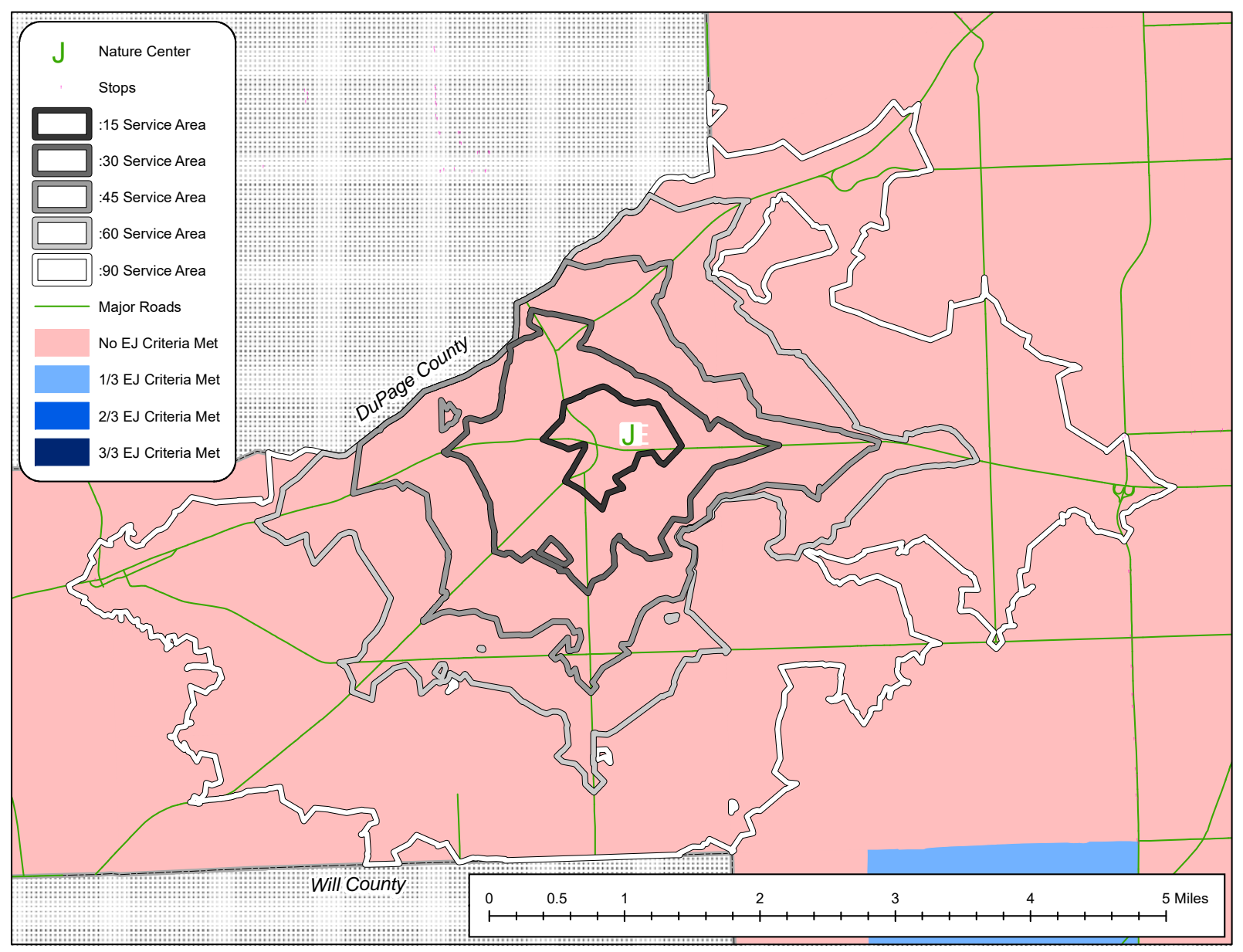

Figure 18: Sagawau 15, 30, 45, 60 \& 90-minute Transit Radius

(Saturday \& Wednesday, 10:00a)

Saturdays, 10:00 am

Miles $^{2}$ of EJ Tract Criteria Covered

Within 15 Minutes via Transit

$\mid>50 \%$ Ethnic $\mid>50 \%$ Black $\mid>50 \%$ Lolnc

\begin{tabular}{l|c|c}
0 & 0 & 0 \\
\hline
\end{tabular}

Within 30 Minutes via Transit

$\mid>50 \%$ Ethnic $\mid>50 \%$ Black $\mid>50 \%$ Lowlnd

\begin{tabular}{l|l|l}
0 & 0 & 0 \\
\hline
\end{tabular}

Within 45 Minutes via Transit

$\mid>50 \%$ Ethnic $\mid>50 \%$ Black $\mid>50 \%$ Lowlnc

\begin{tabular}{l|l|l}
0 & 0 & 0 \\
\hline
\end{tabular}

Within 60 Minutes via Transit

$\mid>50 \%$ Ethnic $\mid>50 \%$ Black $\mid>50 \%$ Lowind

\begin{tabular}{l|c|c}
0 & 0 & 0 \\
\hline
\end{tabular}

Within 90 Minutes via Transit

\begin{tabular}{|c|c|c|}
$>50 \%$ Ethnic & $>50 \%$ Black & $>50 \%$ Lowlnd \\
0 & 0 & 0 \\
\hline
\end{tabular}
Wednesdays, 10:00 am

Miles $^{2}$ of EJ Tract Criteria Covered

Within 15 Minutes via Transit

|>50\% Ethnic | >50\% Black |>50\% Lowlnc \begin{tabular}{l|c|c}
0 & 0 & 0 \\
\hline
\end{tabular}

Within 30 Minutes via Transit $\mid>50 \%$ Ethnic $\mid>50 \%$ Black $>50 \%$ Lowlnc \begin{tabular}{l|l|l}
0 & 0 & 0 \\
\hline
\end{tabular}

Within 45 Minutes via Transit $\mid>50 \%$ Ethnic $\mid>50 \%$ Black $\mid>50 \%$ Lowlnc 0

Within 60 Minutes via Transit $\mid>50 \%$ Ethnic $\mid>50 \%$ Black $\mid>50 \%$ Lowlnc 0 Within 90 Minutes via Transit |>50\% Ethnic |>50\% Black |>50\% Lowlnc| 0 
From the standpoint of potential Nature Express service, Sagawau represents the least likely opportunity for implementation. Not only is its location far from any transit stops, but the surrounding "service area" [based on pedestrian walk time in lieu of available transit] does not include any tracts with EJ characteristics (from any of the three EJ criteria metrics). It should also be noted that while this service area analysis is based entirely on pedestrian walking speeds along presumed sidewalks parallel to existing roadways, many roadways in the area surrounding Sagawau are not pedestrian friendly, often lacking the sidewalks and crosswalks which would permit safe passage. However, the recent construction of the Cal-Sag Trail's western extent (from Lemont to Alsip) places the western terminus of the trail at the entrance to Sagawau, which may offer easier pedestrian/cyclist access to the nature center from locations along the trail.

\subsection{Express Routings}

Based on the above findings, the UTC team has determined that the most promising FPDCC nature centers for Nature Express service are the Hal Tyrell and Sand Ridge nature centers. We are able to offer these conclusions after a geospatial analysis of both environmental justice tracts throughout the County (and their respective centroids within four localized groupings of said EJ tracts) as well as existing transit right-of-ways between these centroids and the nearest FPDCC nature center.

The first step in this process was to determine which census tracts are "max EJ" tracts - those meeting the maximum criteria of Environmental Justice. That information is displayed in figures no. 1 and 2 earlier in this document. Using the four centroids respective to each EJ zone, we can now visualize actual Nature Express routes from those centroids to the nearest Nature Center. 
Figure 19: EJ Zone 1 Nature Express Routing

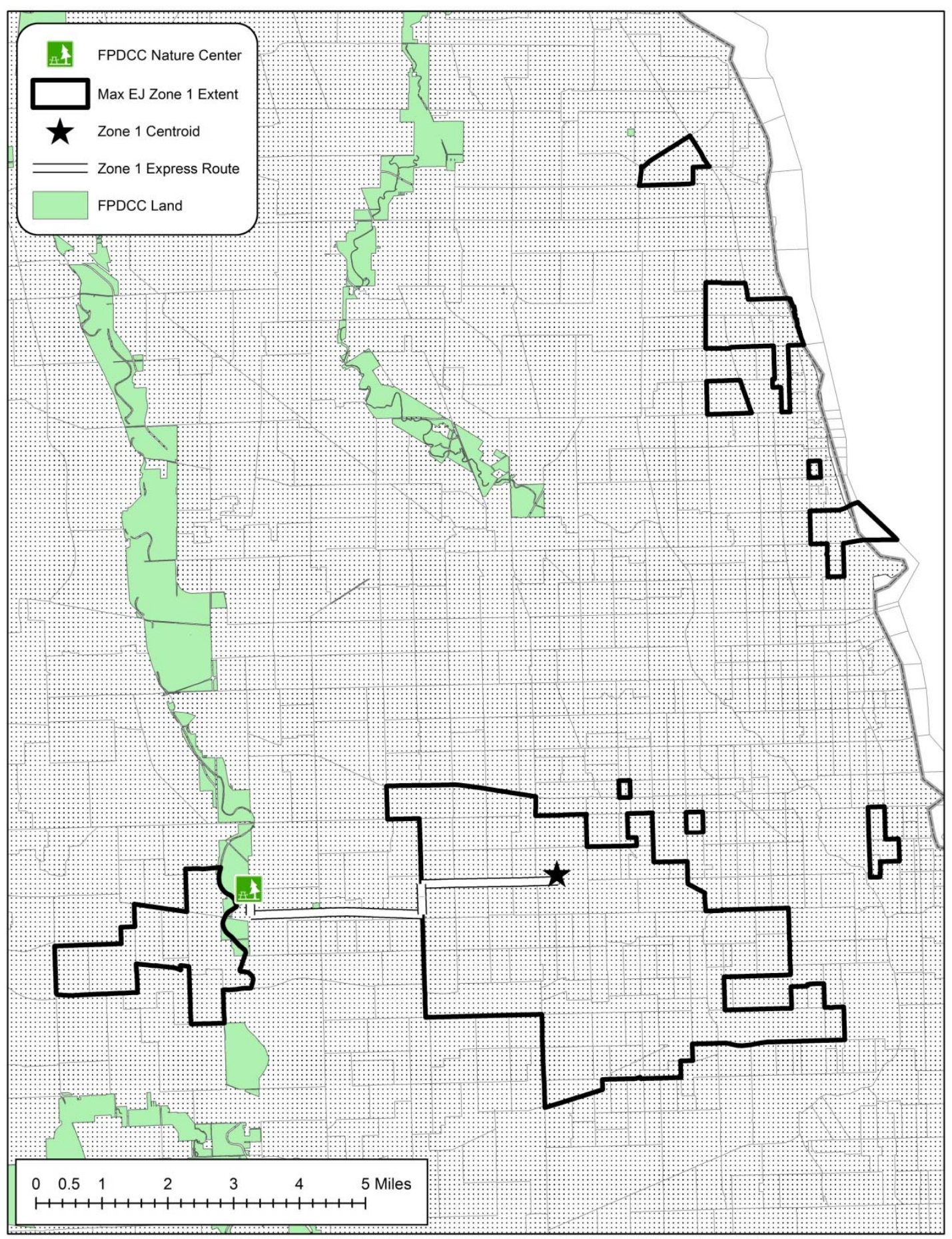

The centroid of EJ Zone 1 is most easily connected to the Hal Tyrell nature center using a combination of Pace and CTA bus routes. Aside from a short distance of roadway very close to the nature center itself, this route is on roadways which already have bus service. 
Figure 20: EJ Zone 2 Nature Express Routing

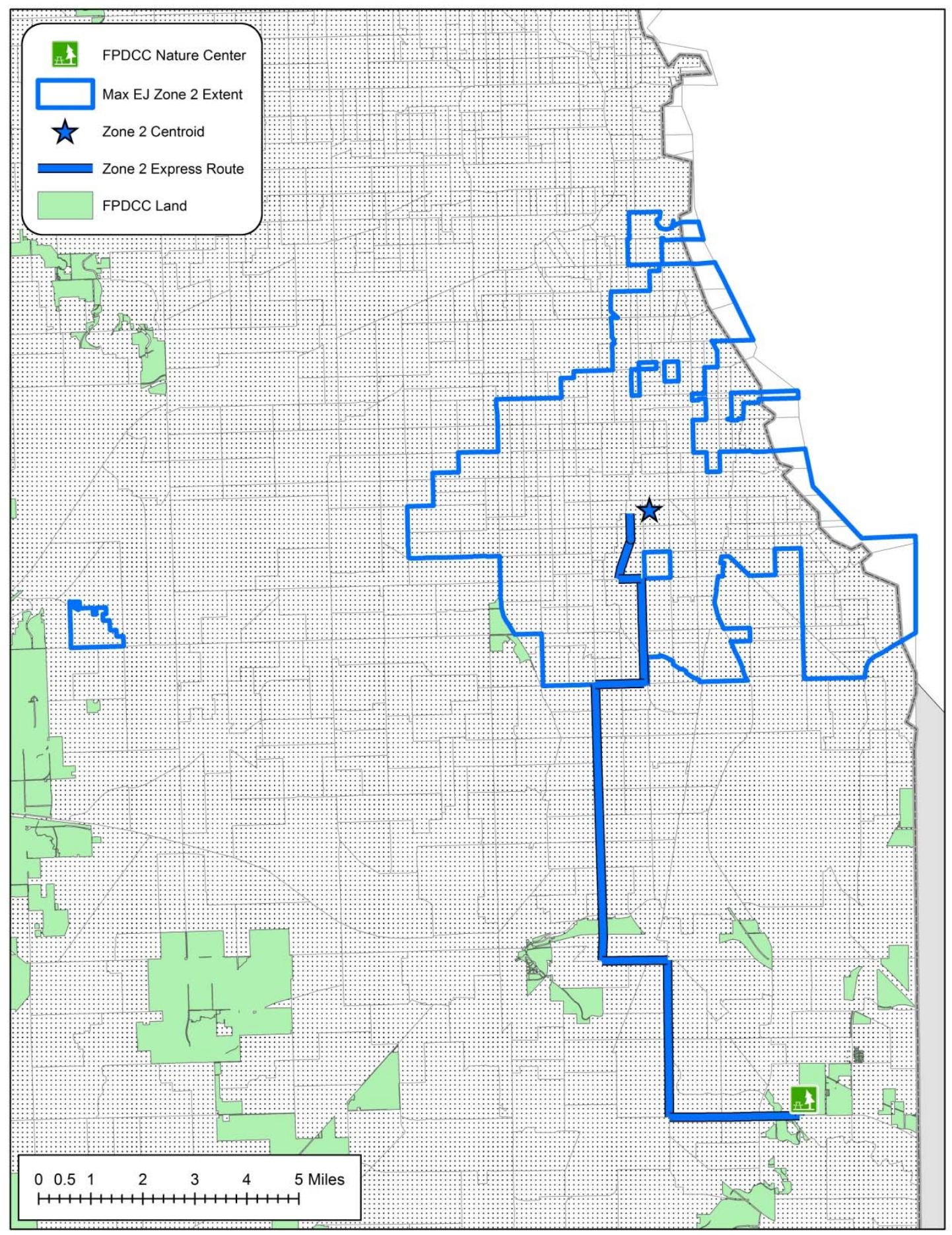

EJ Zone 2's centroid (located within the City of Chicago) is somewhat far from the nearest nature center (Sand Ridge). This hypothetical route parallels a nearby expressway in favor of arterial roadways in the interest of avoiding possible traffic delays. Aside from a short stretch of roadway leading immediately up to Sand Ridge itself, this route utilizes only roadways already served by Pace and CTA. 
Figure 21: EJ Zone 3 Nature Express Routing

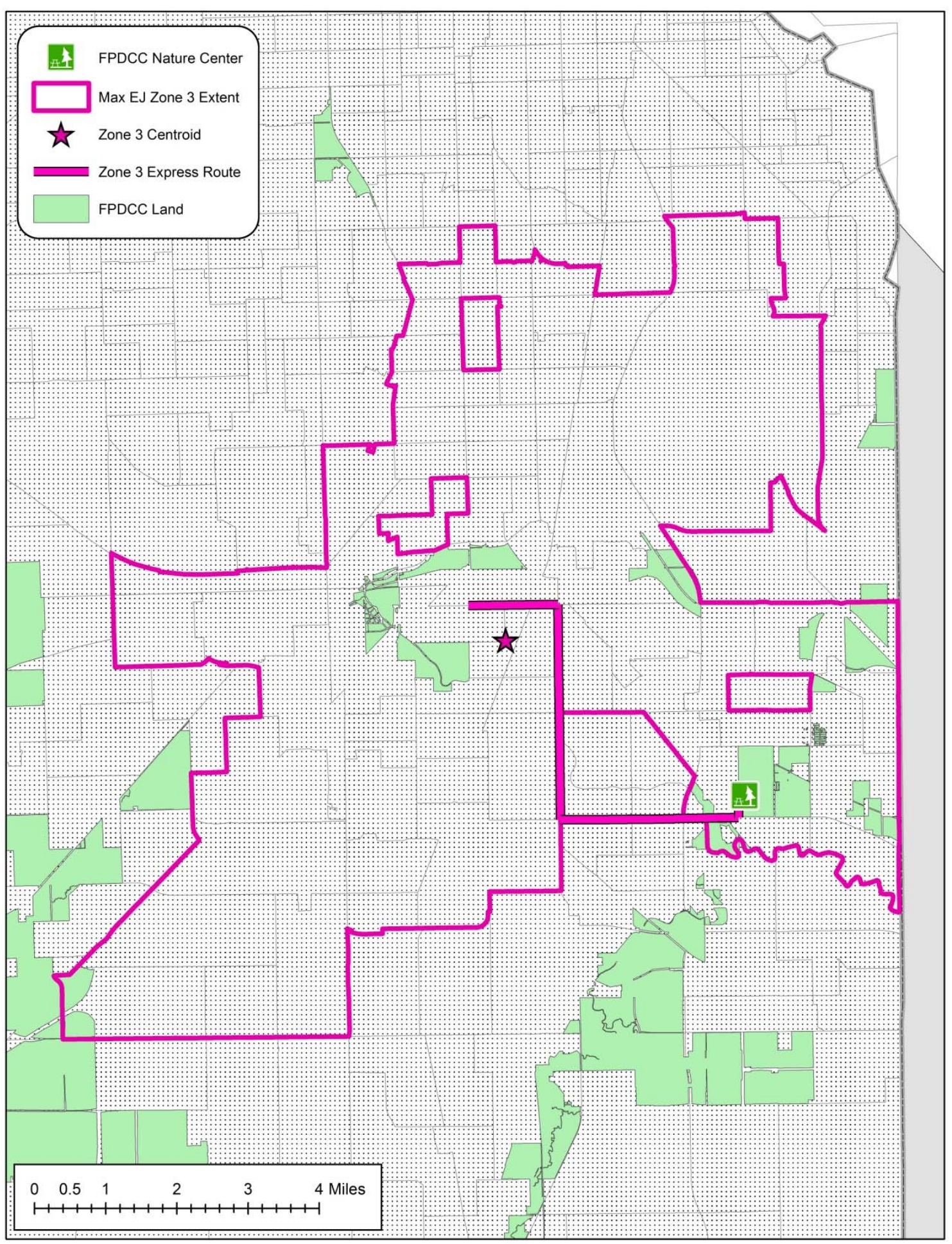

EJ Zone 3 has the luxury of having the nearest nature center (Sand Ridge) located within its extent. This hypothetical route is entirely over roadways already served by Pace, aside from a small stretch leading right to the nature center itself. Zone 3's centroid is in the village of Riverdale. 
Figure 22: EJ Zone 4 Nature Express Routing

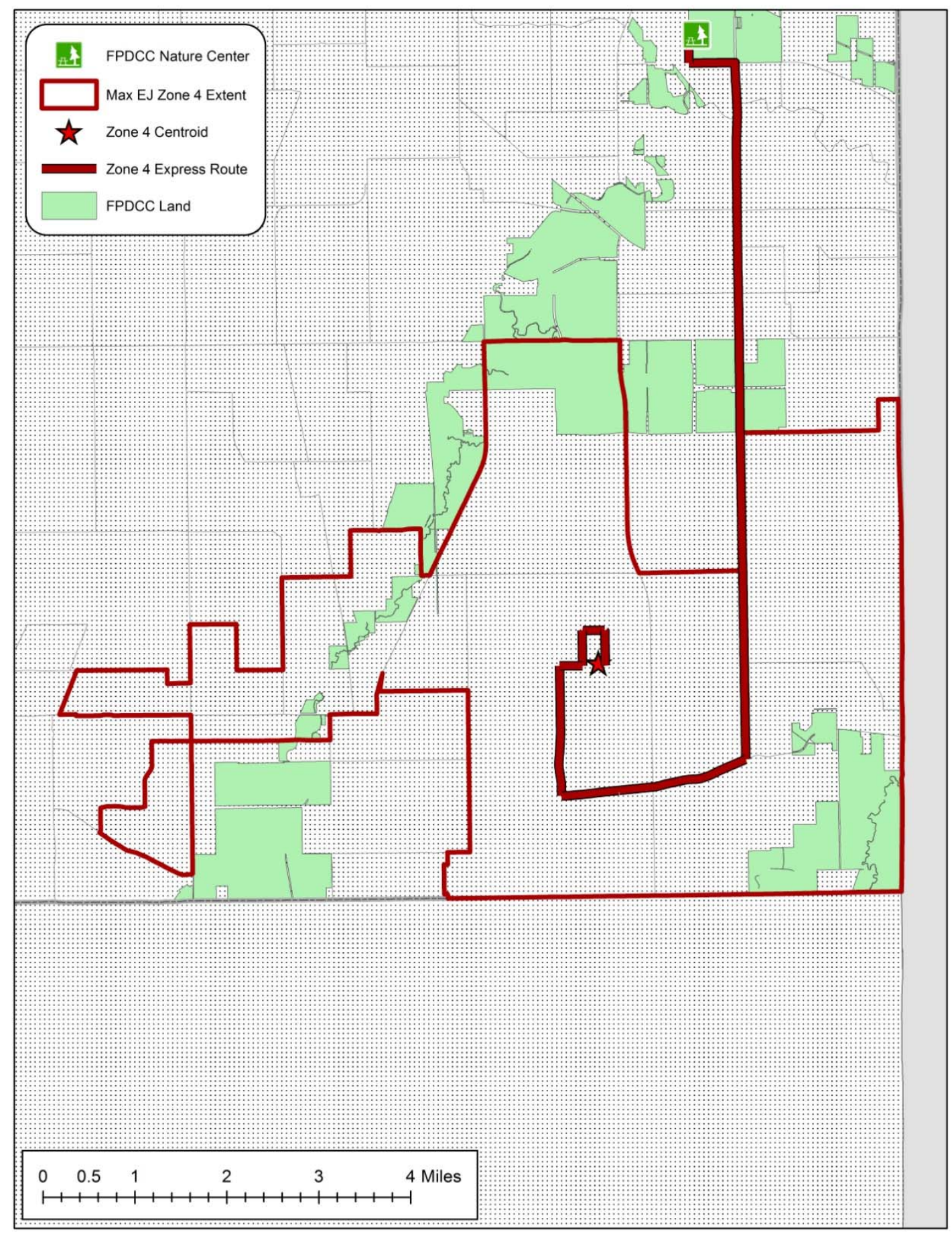

EJ Zone 4 is located south of the nearest nature center (Sand Ridge), and its centroid is in the village of Ford Heights. While most of this proposed route does occur over roads already served by Pace, a small portion of this route is on road not served by any transit provider (routing options are limited due to there being fewer bus routes in this part of Cook County). 


\subsection{Conclusions}

The goals of this study were to document any gaps in transportation access to public land (i.e. forest preserves) for the transit dependent and environmental justice population groups. The study focused on access to leisure activities in forest preserves by public transportation. The case study of Cook County in Northeastern Illinois served to underscore the difficulties of recreational access for population groups that do not have access to an automobile.

The literature on transportation access is littered with numerous studies of peak period travel and focused on connecting homes and employment locations. However, there has not been a lot of work to understand access for leisure, especially by public transportation. In this report, an effort has been made to study the accessibility issues for the target population in a large metropolitan area with a very robust and seemingly well connected public transportation network. The analysis included identifying spatial concentration of EJ population groups and the transit dependent population groups in the county. Using ArcGIS as a tool, the accessibility to the nearest forest preserve in the county was estimated with the help of the GTFS data set that provided the public transportation routes and their schedules.

The results indicate that almost all of the forest preserves included in this study were not accessible by the target population group in Cook County. The reasons for this are many including lack of last mile connections, lack of pedestrian access, bicycle paths/trails, and also in many cases not even a bus route/stop in proximate distance. The research team is recommending a more in-depth follow-up study to understand the institutional and social issues that make this connection difficult to make. This follow up study will also explore feasible mechanisms that can be used to make leisure activities accessible by public transportation a reality. These mechanisms include but are not limited to involvement of the private sector and non-profit agencies in exploring feasible solutions such as the establishment of Transportation Management Associations (TMA) for leisure activities.

\subsection{References}

Fruin, G, and P. S. Sriraj, Approach of Environmental Justice to Evaluate the Equitable Distribution of a Transit Capital Improvement Program, TRR 1924, Journal of the Transportation Research Record, National Academies of Sciences, Washington D.C., 2005

http://www.rtams.org/rtams/gtfs.jsp, accessed July 2016

Sriraj, P. S., G. Fruin, and S. Mcneil, Analysis of the Environmental Justice Compliance of the Chicago Transit Authority, Proceedings of the 2003 Mid-Continent Transportation Research Symposium, lowa, 2003.

http://fpdcc.com/nature-centers/, accessed February 2016. 